\title{
Obliterative Bronchiolitis
}

\section{Isabela S. Silva and Nestor L. Müller}

\begin{abstract}
Summary
Obliterative bronchiolitis $(\mathrm{OB})$ is a condition characterized by inflammation and fibrosis of the bronchiolar walls resulting in narrowing or obliteration of the bronchiolar lumen. The most common causes are childhood lower respiratory tract infection, hematopoietic stem cell or lung and heart-lung transplantation, and toxic fume inhalation. The most frequent clinical manifestations are progressive dyspnea and dry cough. Pulmonary function tests demonstrate airflow obstruction and air trapping. Radiographic manifestations include reduction of the peripheral vascular markings, increased lung lucency, and overinflation. The chest radiograph, however, is often normal. High-resolution CT is currently the imaging modality of choice in the assessment of patients with suspected or proven OB. The characteristic findings on high-resolution CT consist of areas of decreased attenuation and vascularity (mosaic perfusion pattern) on inspiratory scans and air trapping on expiratory scans. Other CT findings of OB include bronchiectasis and bronchiolectasis, bronchial wall thickening, small centrilobular nodules, and three-in-bud opacities. Recent studies suggest that hyperpolarized ${ }^{3} \mathrm{He}$-enhanced magnetic resonance imaging may allow earlier recognition of obstructive airway disease and therefore may be useful in the diagnosis and follow-up of patients with OB.
\end{abstract}

Key Words: Bronchiolitis; bronchiolitis obliterans; bronchiolitis obliterans syndrome; constrictive bronchiolitis; computed tomography; obliterative bronchiolitis; small airways disease.

\section{INTRODUCTION}

Bronchiolitis is a generic term applied to various inflammatory and fibrosing diseases that affect the small airways, which by definition are airways that measure less than $2 \mathrm{~mm}$ in diameter (i.e., primarily membranous and respiratory bronchioles) (2, 2). Bronchiolitis is common and occurs in various clinical settings (7-5). Several classification schemes have been proposed based on histologic features, etiology, or computed tomography (CT) findings $(2,3] 6,7)$. Although none of these classification schemes is widely accepted and there is controversy about the classification of some of the subtypes of bronchiolitis, there is overall agreement on the histologic, radiologic, and clinical features of obliterative bronchiolitis (OB).

\section{DEFINITION AND TERMINOLOGY}

Obliterative bronchiolitis, also known as constrictive bronchiolitis, bronchiolitis obliterans, or cicatricial bronchiolitis, is a condition characterized by inflammation and fibrosis of the bronchiolar walls and contiguous tissues resulting in narrowing and, in some cases, complete obliteration of the bronchiolar lumen (7, 2, 8). OB may result from a large number of acute and chronic processes and may occasionally be idiopathic (Table 1 . 
Table 1

Most Common Conditions Associated with Obliterative Bronchiolitis

Childhood respiratory infection, most commonly adenovirus, respiratory syncytial virus, and Mycoplasma pneumoniae bronchiolitis and bronchopneumonia

Chronic rejection following lung and heart-lung transplantation

Chronic graft-versus-host disease following allogeneic hematopoietic stem-cell transplantation

Postinhalational

Nitrogen dioxide (Silo filler's disease), ammonia, chlorine, fire smoke, hydrogen bromide, hydrogen selenide, sulfur dioxide, thionyl chloride, and diacetyl (2,3-butanedione)

Ingested toxins

Sauropus androgynus (vegetable alleged to help weight control)

Connective tissue disorders, most commonly rheumatoid arthritis. Occasionally, Sjögren's syndrome, systemic lupus erythematosus, and scleroderma

Drugs

D-penicillamine, lamustine, and gold therapy

Inflammatory bowel diseases

Ulcerative colitis and Crohn's disease

Cryptogenic (idiopathic)

Other conditions

Diffuse idiopathic neuroendocrine cell hyperplasia with multiple carcinoid tumorlets

Eosinophilic fasciitis

Stevens-Johnson syndrome and paraneoplastic pemphigus

Asthma

Bronchiectasis

Cystic fibrosis

Hypersensitivity pneumonitis

Sarcoidosis

There has been historical confusion between the term "bronchiolitis obliterans" as it refers to OB and the term "bronchiolitis obliterans organizing pneumonia" (BOOP) $9-11$ ). The histologic hallmark of BOOP is the presence of buds of loose granulation tissue, termed Masson bodies, within alveolar ducts and air spaces, that is, organizing pneumonia (7, 2, 12). The patients may or may not have granulation polyps within terminal and respiratory bronchioles, but they rarely have fibrosis within the bronchiolar walls or peribronchiolar tissues, that is, they do not have OB. Because the predominant clinical, histologic, and radiologic manifestations of BOOP are those of organizing pneumonia, the American Thoracic Society and European Respiratory Society multidisciplinary consensus classification recommended that the term BOOP be replaced by the term organizing pneumonia and idiopathic BOOP by cryptogenic organizing pneumonia (12). Organizing pneumonia may result from various causes or underlying pathologic processes including pulmonary infection, aspiration, collagen vascular disorders, drugs, radiation, inhalational injury, and hypersensitivity pneumonitis. Cryptogenic organizing pneumonia is currently classified as a form of idiopathic interstitial pneumonia (12 13) and is beyond the scope of this chapter. We will limit our discussion to the histologic, clinical, and radiologic findings of $\mathrm{OB}$. 


\section{CLINICAL FEATURES}

The most common clinical manifestations of $\mathrm{OB}$ consist of progressive dyspnea, nonproductive cough, and airflow obstruction, which usually progress over weeks to months. Associated symptoms may include chest pain, respiratory distress, and cyanosis (14). Auscultation of the chest may reveal crackles and midinspiratory squeaks. Occasionally, patients may present with pneumothorax or pneumomediastinum $15-17$. In many cases, OB is first detected on CT in patients with no apparent symptoms or with symptoms secondary to associated conditions such as bronchiectasis or asthma.

A presumptive diagnosis of $\mathrm{OB}$ can often be made with a high degree of confidence based on a clinical history of persistent symptoms of obstructive pulmonary disease, demonstration of airflow obstruction on pulmonary function tests, and characteristic findings on high-resolution CT. However, the clinical diagnosis of $\mathrm{OB}$ requires exclusion of other causes of chronic airway obstruction, including emphysema, chronic bronchitis, and asthma 18 19).

\section{PULMONARY FUNCTION TESTS}

The functional manifestations of $\mathrm{OB}$ are those of airflow obstruction, and air trapping with reduction in forced expiratory volume in $1 \mathrm{~s}\left(\mathrm{FEV}_{1}\right)$, increased residual volume $(\mathrm{RV})$ and $\mathrm{RV}$ to total lung capacity (TLC) ratio, and no significant response to bronchodilators (8). The TLC is often normal until the late stages of the disease, which accounts for the usually normal lung volumes on the chest radiograph. Lung diffusion as measured by the carbon monoxide diffusing capacity (DLCO) is typically within normal limits, which allows distinction from emphysema.

\section{HISTOLOGIC FINDINGS}

Obliterative bronchiolitis is characterized histologically by concentric or, less commonly eccentric, thickening of terminal and respiratory bronchiolar walls by submucosal collagenous fibrosis resulting in progressive narrowing and distortion of the bronchiolar lumen. Associated features include epithelial metaplasia, smooth muscle hyperplasia, bronchiolectasis with mucous stasis, and patchy chronic inflammation (cellular bronchiolitis) (Fig. 11 (7,2). Severe fibrosis may result in complete obliteration of the bronchiolar lumen, the bronchiole being replaced by scar tissue (Fig. 2). In such cases, the diagnosis may be difficult to make histologically, the obliterated bronchiole being misinterpreted as being a small scar.

The pathogenesis of OB is not well known. The initial event is believed to be bronchiolar inflammation, with resulting epithelial necrosis. The inflammation can involve the mucosa, submucosa, and peribronchiolar parenchyma and be followed by the development of fibrous connective tissue that compromises the bronchiolar lumen. Significant involvement of the interstitium is uncommon. OB may be classified as "active" when an inflammatory component is present or "inactive" when inflammation is absent 20).

Definitive diagnosis of $\mathrm{OB}$ requires lung biopsy. The patchy distribution of the disease and inadequate tissue sampling result in a large percentage of false-negative diagnosis on transbronchial biopsy specimens 2126 ). It should be noted that even on surgical biopsy specimens, subtle changes or completely distorted and scarred bronchioles may be missed on routine hematoxylin-eosin stains. Optimal assessment requires the use of elastic tissue stains (Fig. 3] 2, 214). Because of the subtlety of the histologic findings, lung biopsies in patients with BO may occasionally be read as normal or near-normal. In such patients, the presence of typical imaging findings should prompt a request for review, re-staining, or re-sectioning of the biopsy specimen. 


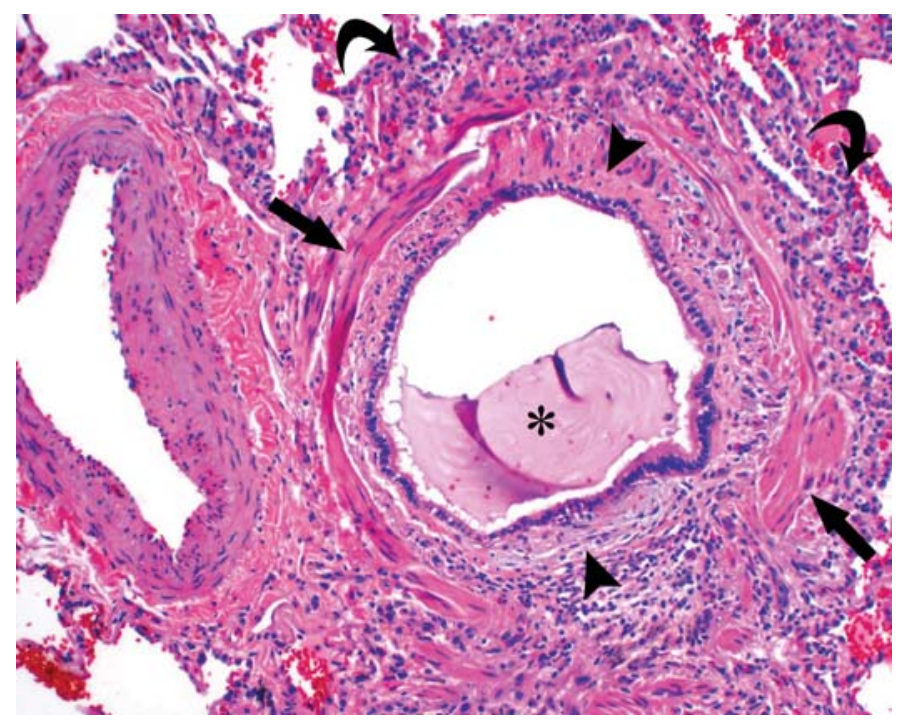

Fig. 1. Obliterative bronchiolitis. Surgical lung biopsy specimen shows small bronchiole with submucosal fibrosis (arrowheads), muscle hypertrophy (straight arrows), peribronchiolar inflammation (curved arrows), and associated mucostasis (asterix). The findings are characteristic of mild obliterative bronchiolitis $(\mathrm{H}$ and $\mathrm{E}$, intermediate magnification) (Courtesy of Dr. Thomas Colby, Mayo Clinic, Scottsdale).

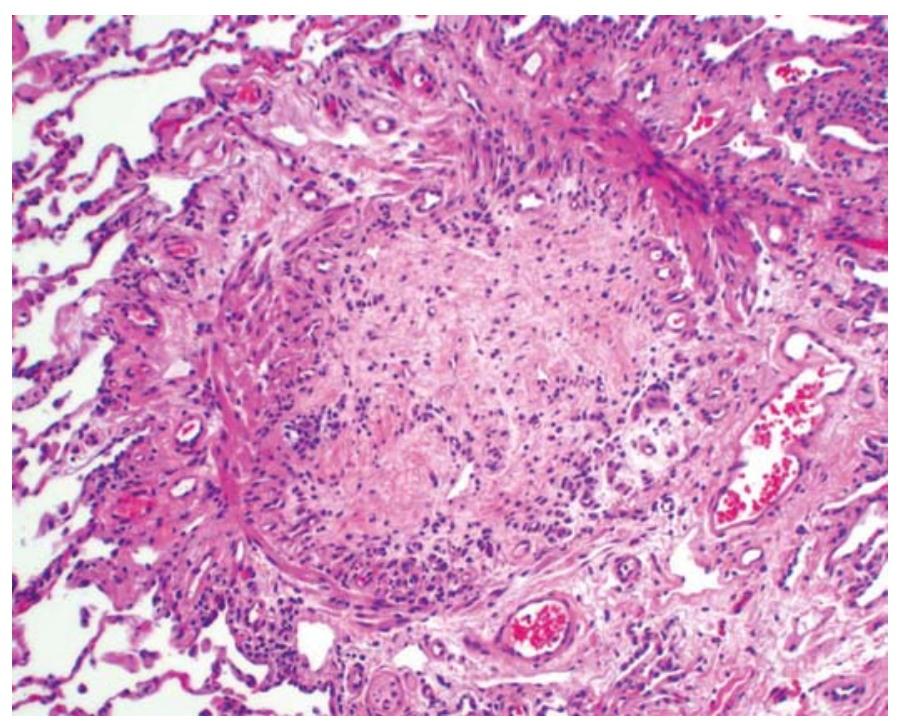

Fig. 2. Obliterative bronchiolitis. Surgical lung biopsy specimen demonstrates complete obliteration of bronchiolar lumen by fibrous tissue (H and E, intermediate magnification). (Courtesy of Dr. Thomas Colby, Mayo Clinic, Scottsdale). 
A)

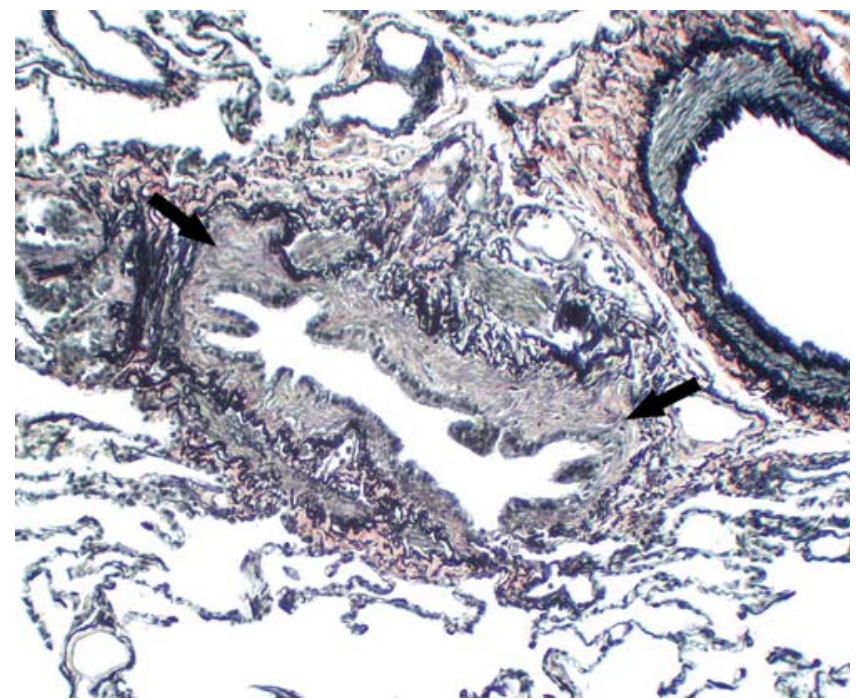

B)

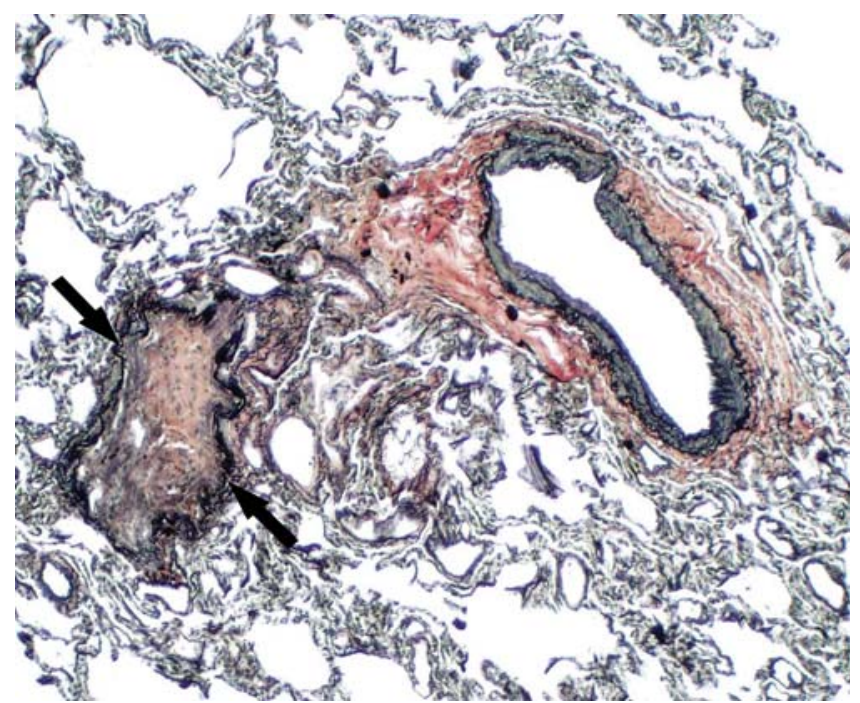

Fig. 3. Obliterative bronchiolitis. Surgical lung biopsy specimen shows bronchiole with concentric submucosal scarring (arrows, A), and completely obliterated bronchiole (B) in which the preexisting elastica is highlighted with elastic tissue stain (arrows) (elastic tissue stain, intermediate magnification) (Courtesy of Dr. Thomas Colby, Mayo Clinic, Scottsdale).

\section{IMAGING FINDINGS}

The most common imaging modalities used in the assessment of patients with suspected or proven OB are chest radiography and high-resolution CT. Scintigraphy plays a limited role. Ventilation/perfusion scans generally reveal diminished ventilation in the lung periphery; perfusion abnormalities may also be present, but these are usually much milder than the ventilation abnormalities 27 28). Recently, it has been shown that magnetic resonance (MR) allows functional imaging of pulmonary ventilation and perfusion with the additional benefit of lack of radiation (29). Hyperpolarized ${ }^{3} \mathrm{He}$-enhanced MR may allow earlier recognition of obstructive airway disease and therefore 
be useful in the early recognition and follow-up of patients with $\mathrm{OB}$ 30 37). Although potentially useful, functional MR imaging is only available at a very small number of centers and remains an investigational tool.

\subsection{Chest Radiography}

In patients with mild-to-moderate $\mathrm{OB}$, the chest radiograph is often normal. The earliest manifestations, which are often quite subtle, consist of increased lung lucency and reduction of the peripheral vascular markings. Severe disease results in hyperinflation detected by the overall increase in lung volumes, flattening of the diaphragm, and increase in the retrosternal airspace (Fig. 4). Other findings include increased bronchial markings, bronchiectasis, and, occasionally, nodular or reticulonodular opacities 832 36) (Table 2).

There is poor correlation between the radiographic findings and the clinical and functional severity of disease 37) and considerable inter-observer and intra-observer variability in interpretation of findings 38). The chest radiograph therefore plays a limited role in the diagnosis and follow-up of patients with $\mathrm{OB}$.

\subsection{Computed Tomography Findings}

High-resolution CT is currently the imaging modality of choice in the assessment of patients with suspected or proven small airways disease, being superior to chest radiography in demonstrating the presence and extent of abnormalities (39). Because the bronchiolar wall is too thin to be visualized on high-resolution $\mathrm{CT}$, even in patients with $\mathrm{OB}$, the analysis of the $\mathrm{CT}$ images is limited to assessment

A)

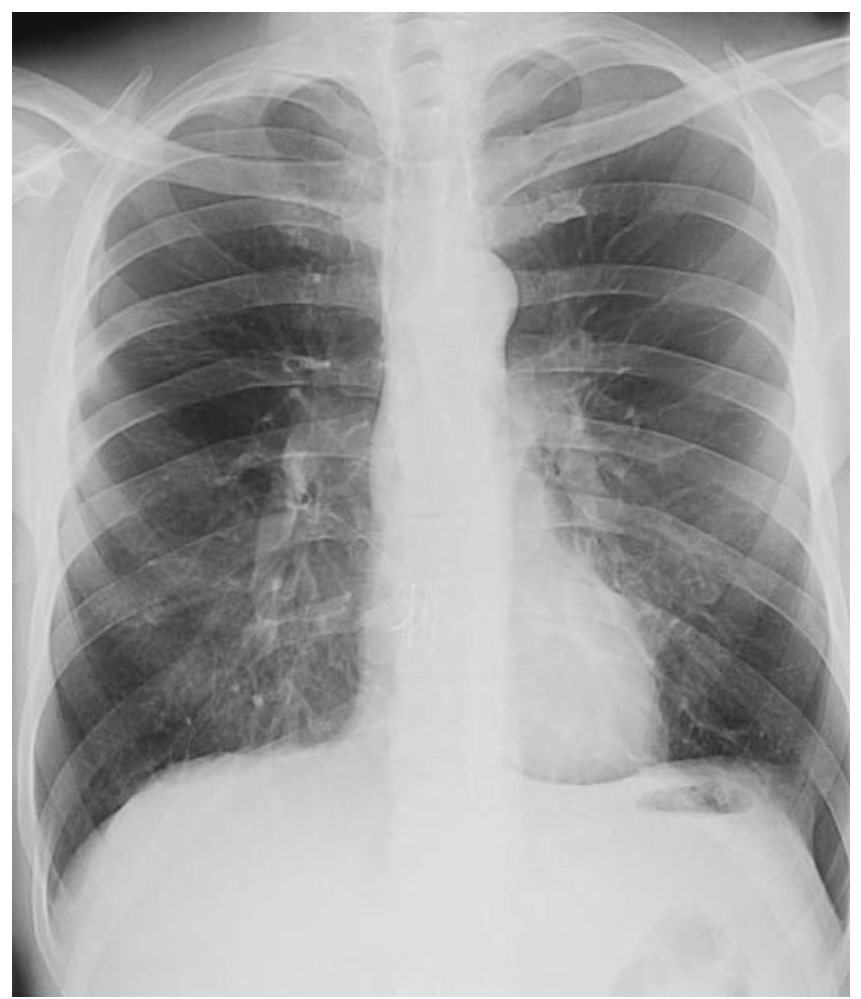

Fig. 4. (Continued) 
B)

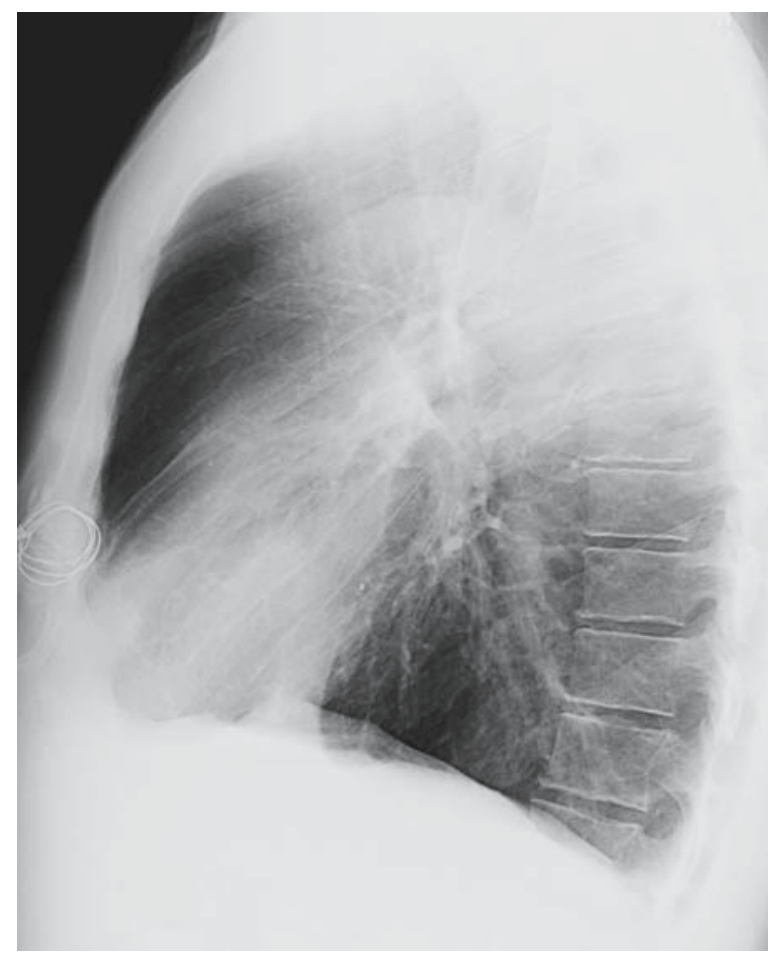

Fig. 4. Obliterative bronchiolitis on chest radiography. (A) Posteroanterior chest radiograph show increased lung volumes and reduction of the peripheral vascular markings. (B) Lateral view shows increased retrosternal airspace and flattening of the diaphragm. The patient was a 44-year-old man with obliterative bronchiolitis following bilateral lung transplantation for cystic fibrosis.

of secondary signs related to the small airway obstruction. The main CT finding of OB on CT scans performed at end-inspiration is a geographic inhomogeneity of lung attenuation (mosaic attenuation pattern), seen in $40-80 \%$ of patients $40-47$ ) (Table 3. This pattern consists of patchy lobular, segmental or, occasionally, lobar regions of decreased attenuation and vascularity and blood flow redistribution to relatively normal lung resulting in areas of normal or increased attenuation and

Table 2

\section{Radiographic Findings of Obliterative Bronchiolitis}

Chest radiograph may be normal in mild to moderate disease

Common findings

Increased lung lucency

Reduction of peripheral vascular markings

Late findings

Hyperinflation

Flattening of the diaphragm

Increased retrosternal airspace

Ancillary findings

Prominent bronchial markings, bronchiectasis, and nodular or reticulonodular opacities 
Table 3

High-Resolution CT Findings of Obliterative Bronchiolitis

\author{
Common findings \\ Decreased attenuation and vascularity \\ Mosaic perfusion pattern \\ Air trapping at expiratory images \\ Ancillary findings \\ Bronchiectasis and bronchiolectasis \\ Bronchial wall thickening \\ Centrilobular nodules \\ Tree-in-bud opacities
}

increased vascularity (mosaic perfusion pattern) (Fig. 5) (6, 8, 46). The areas of decreased attenuation result from decreased perfusion of hypoventilated alveoli distal to obstructed bronchioles. The abnormalities may be subtle on inspiratory images. The presence of airflow obstruction and air trapping is usually easier to detect on CT scans performed during maximal expiration or at end-expiration (48-51). Regions with airflow obstruction because of OB show no decrease in volume or less decrease in volume than the adjacent uninvolved lung and therefore remain lucent while the remaining lung increases in attenuation. This results in increased contrast between areas with airflow obstruction and normal lung facilitating recognition of air trapping on high-resolution CT (Fig. 6). Expiratory CT images may demonstrate air trapping in patients with normal findings on inspiratory scans (Fig. 7) 48 52 52 55). The extent of air trapping on expiratory $\mathrm{CT}$ in patients with OB correlates with severity of airflow obstruction and air trapping on pulmonary function tests 18). CT performed during maximal expiratory maneuver or at end-expiration therefore plays an important role and is recommended in the initial evaluation and follow-up of patients with $\mathrm{OB}(50,52)$.
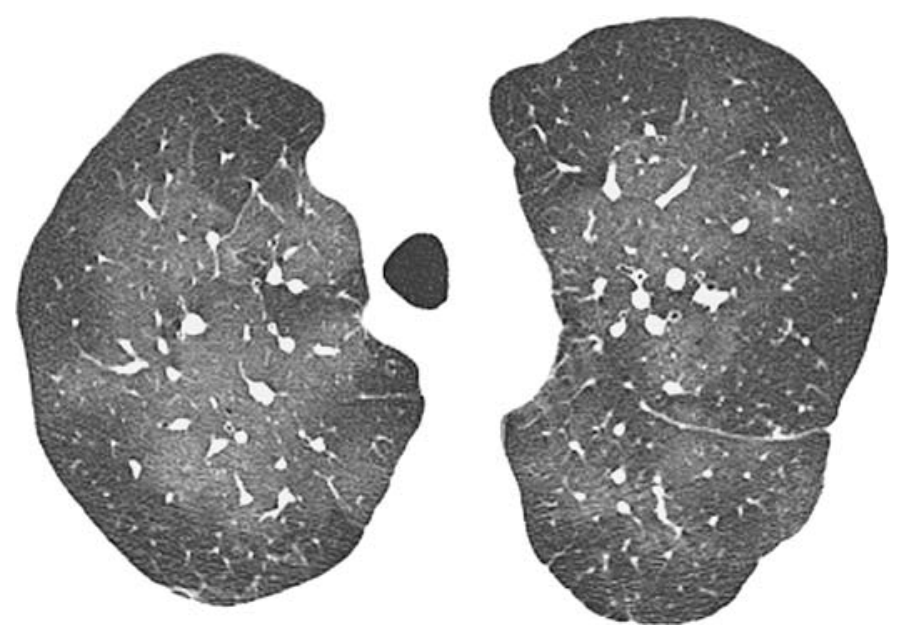

Fig. 5. Mosaic perfusion pattern. High-resolution CT image demonstrates geographic areas of decreased attenuation and vascularity interspersed with areas of increased attenuation that contain enlarged vessels, reflecting pulmonary blood flow redistribution. The patient was 48-year-old man with obliterative bronchiolitis. 
A)
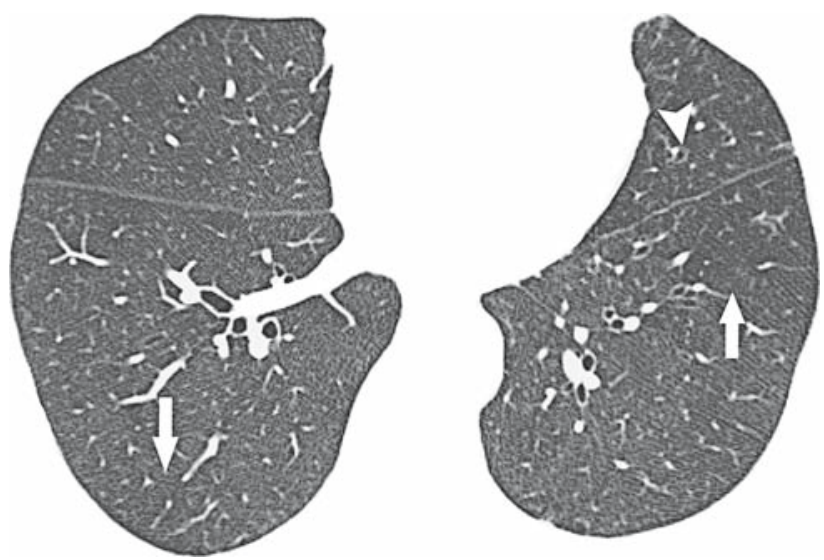

B)
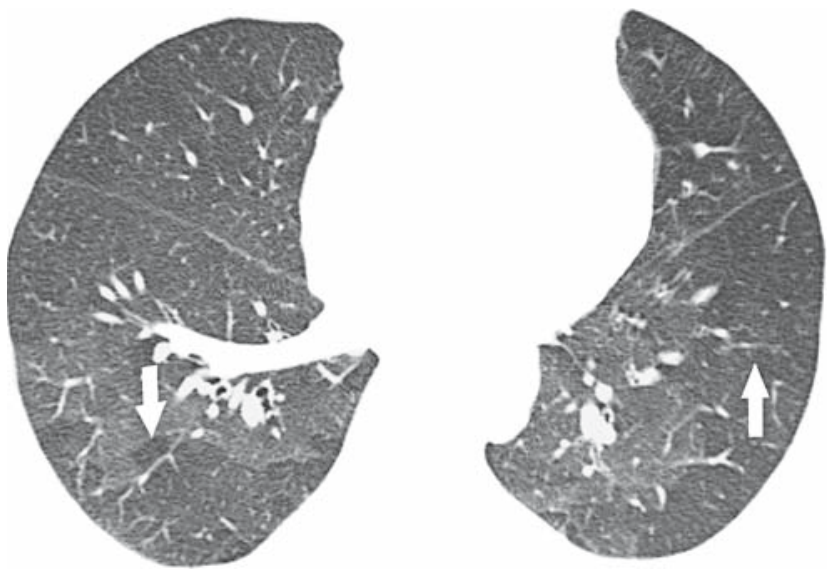

Fig. 6. Air trapping in obliterative bronchiolitis. (A) High-resolution CT scan obtained at end-inspiration shows subtle areas of decreased attenuation (straight arrows). Also noted is mild bronchiectasis in the lingula and anteromedial basal segment of the left lower lobe (arrowhead). (B) High-resolution CT scan performed at the end of maximal expiration demonstrates air trapping (arrows). The patient was a 66-year-old woman with cryptogenic obliterative bronchiolitis.

Several studies have suggested that post-processing of high-resolution CT images particularly with the use of minimum intensity projection (MinIP) reconstructions improves the detection of subtle areas of low attenuation encountered in patients with emphysema and small airways disease (Fig. 8). $56-61$ ) These techniques may be particularly helpful in patients with high clinical suspicion for OB and otherwise apparently normal CT findings.

Ancillary high-resolution CT findings of $\mathrm{OB}$ include central and peripheral bronchial dilatation (bronchiectasis), bronchiolectasis, and bronchial wall thickening, findings that have been reported in 20-90\% of patients (Fig. 9. 218 40, 43, 46, 62) Less common CT findings of OB include small centrilobular nodules and tree-in-bud opacities representing thick-walled bronchioles with or without intraluminal debris, seen in up to 30\% of patients (Fig. 100 (see Table 3) 47).

In the appropriate clinical setting, the presence of mosaic perfusion, air trapping, and ancillary $\mathrm{CT}$ findings can be diagnostic of OB. It should be emphasized, however, that mosaic perfusion is a nonspecific finding seen in a number of conditions, that mild air trapping is commonly seen in normal subjects, and that there is overlap between the high-resolution CT manifestations of OB and the findings seen in other causes of airway obstruction such as asthma and emphysema (19). 
A)
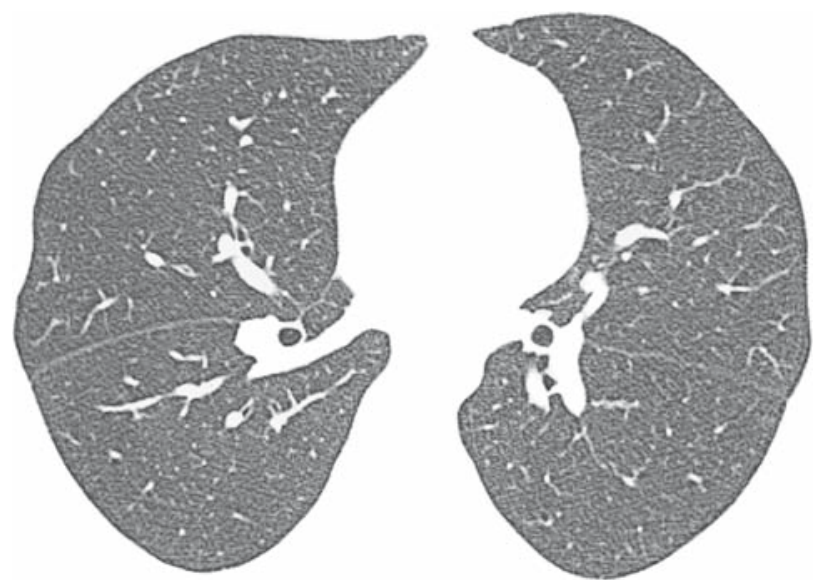

B)
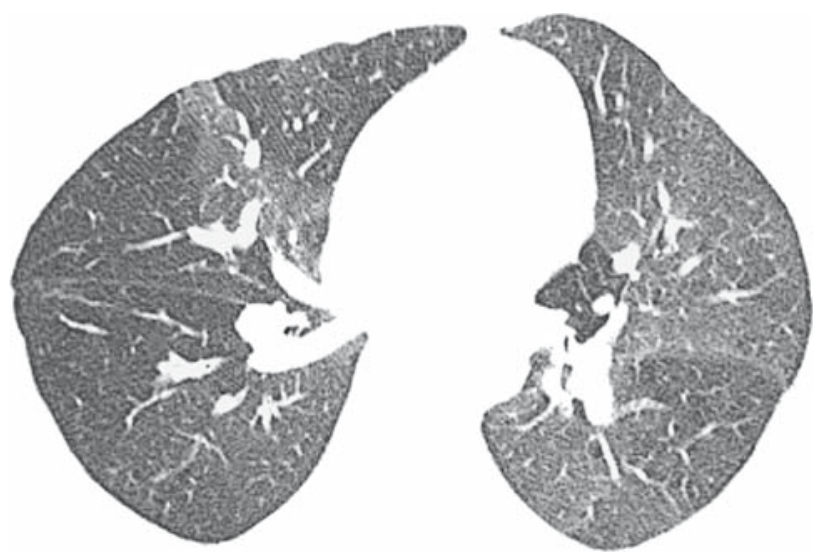

C)
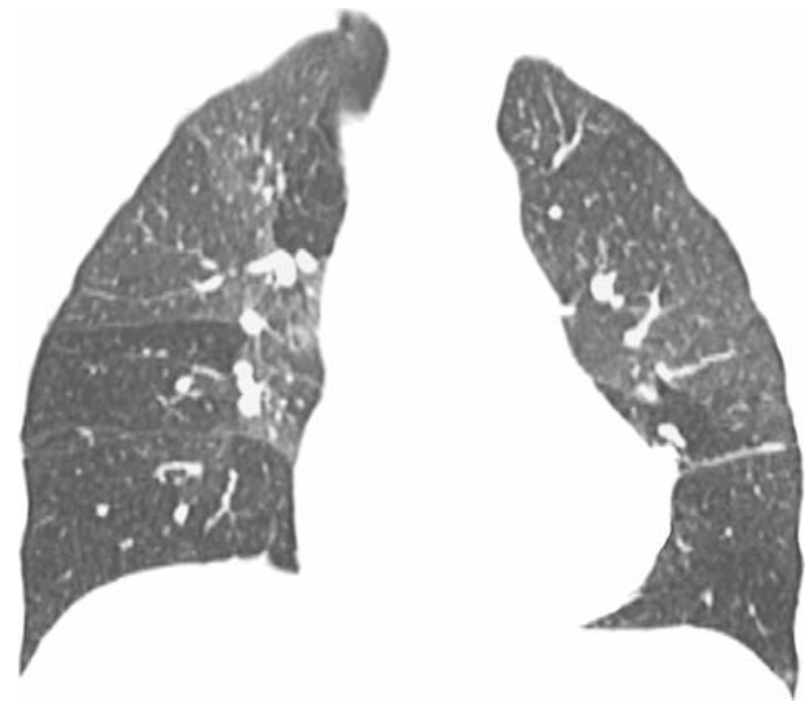

Fig. 7. Normal inspiratory CT in obliterative bronchiolitis. (A) High-resolution CT scan obtained at endinspiration on a multidetector CT scanner is within normal limits. (B) Expiratory image at the same level as (A) demonstrates patchy lobular and segmental areas of air trapping. (C) Coronal reformatted image better demonstrates the extent of air trapping. The patient was a 54-year-old woman with postinfectious obliterative bronchiolitis. 
A)
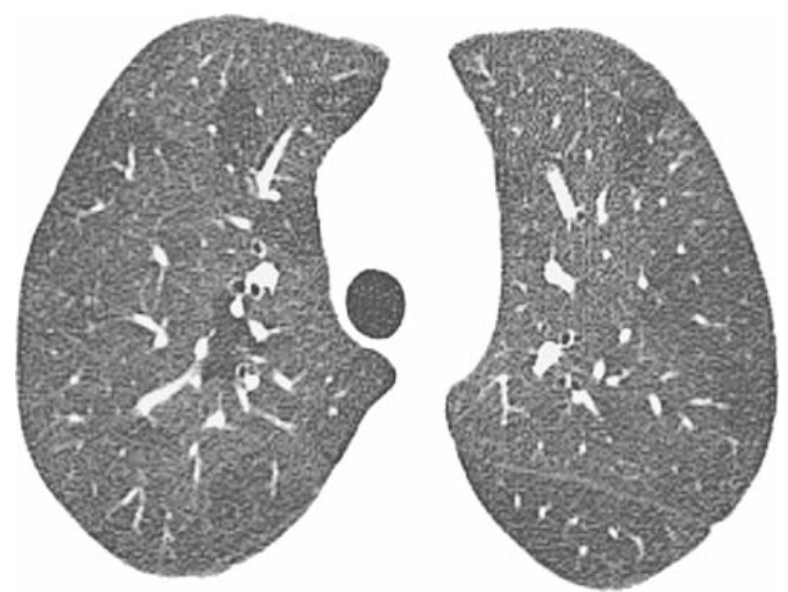

B)
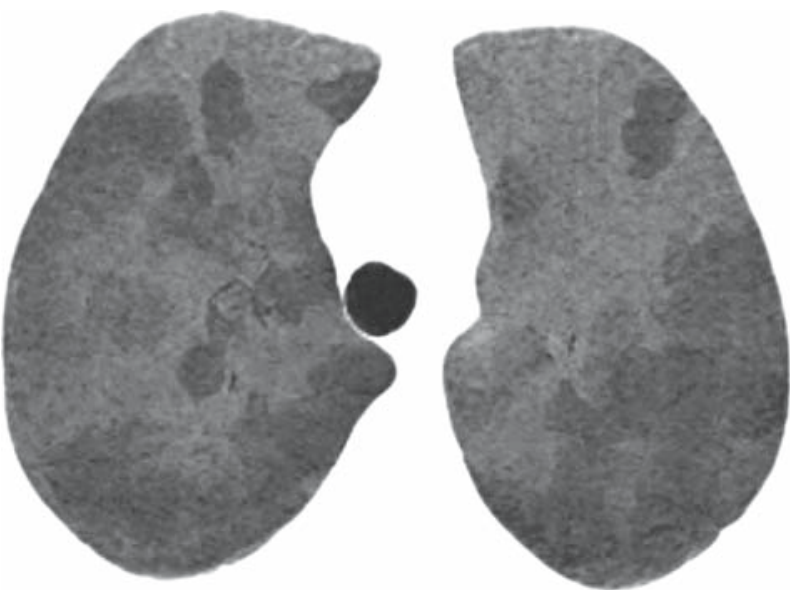

C)

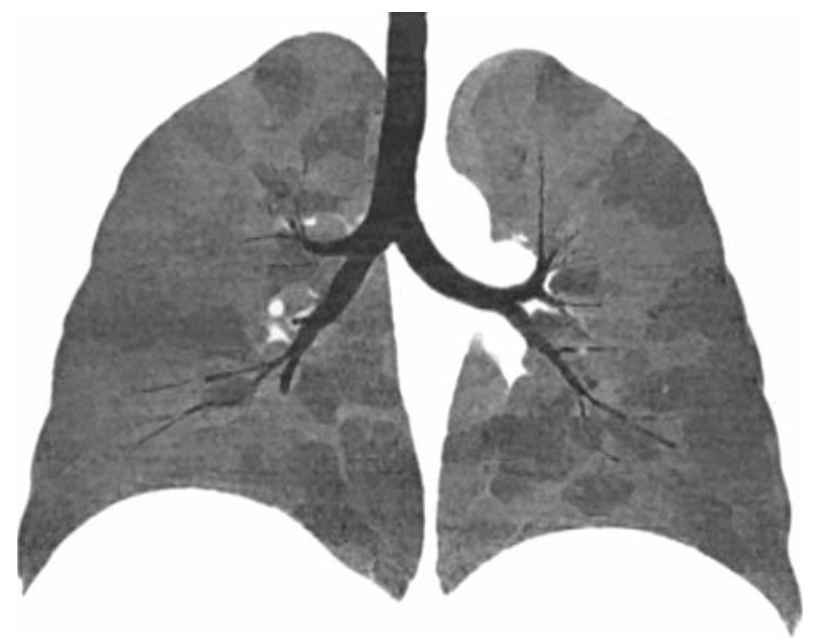

Fig. 8. Minimum intensity projection (MinIP) in the assessment of obliterative bronchiolitis. (A) Highresolution CT scan obtained in a multidetector CT scanner at the level of aortic arch shows subtle lobular areas of decreased attenuation and vascularity. (B and $\mathbf{C}$ ) Cross-sectional and coronal minimum intensity projection (MinIP) reformation images improve the detection of lobular areas of decreased attenuation. The patient was a 29-year-old woman with chronic graft-versus-host disease and obliterative bronchiolitis 1 year after allogeneic hematopoietic stem-cell transplantation. 
A)
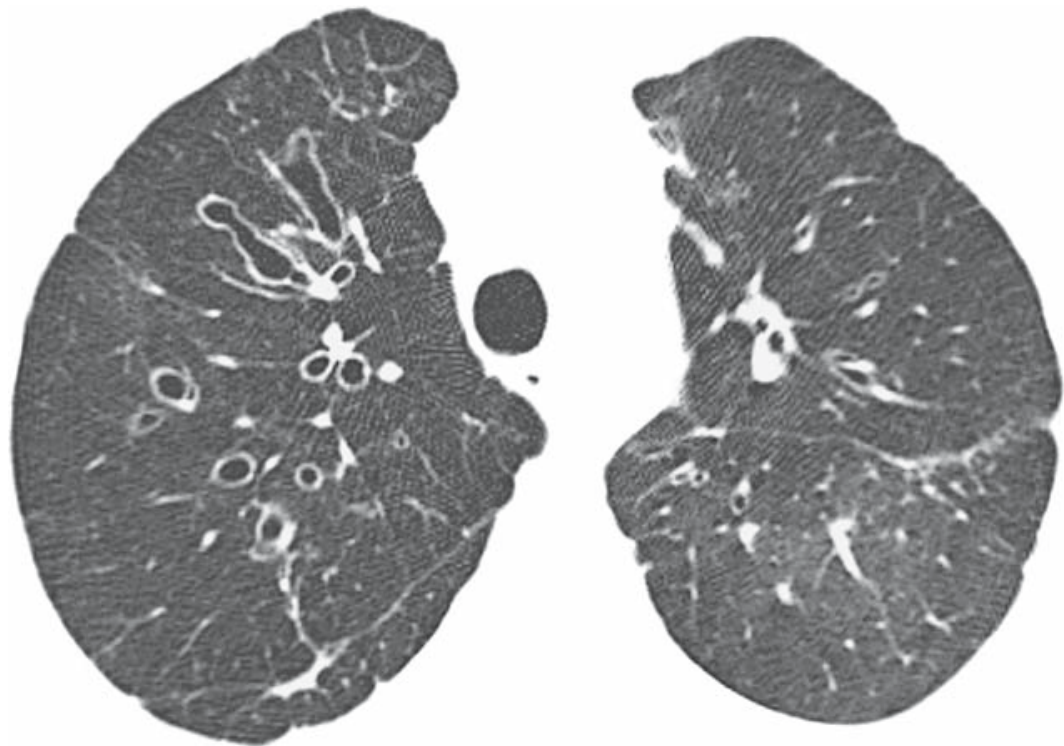

B)

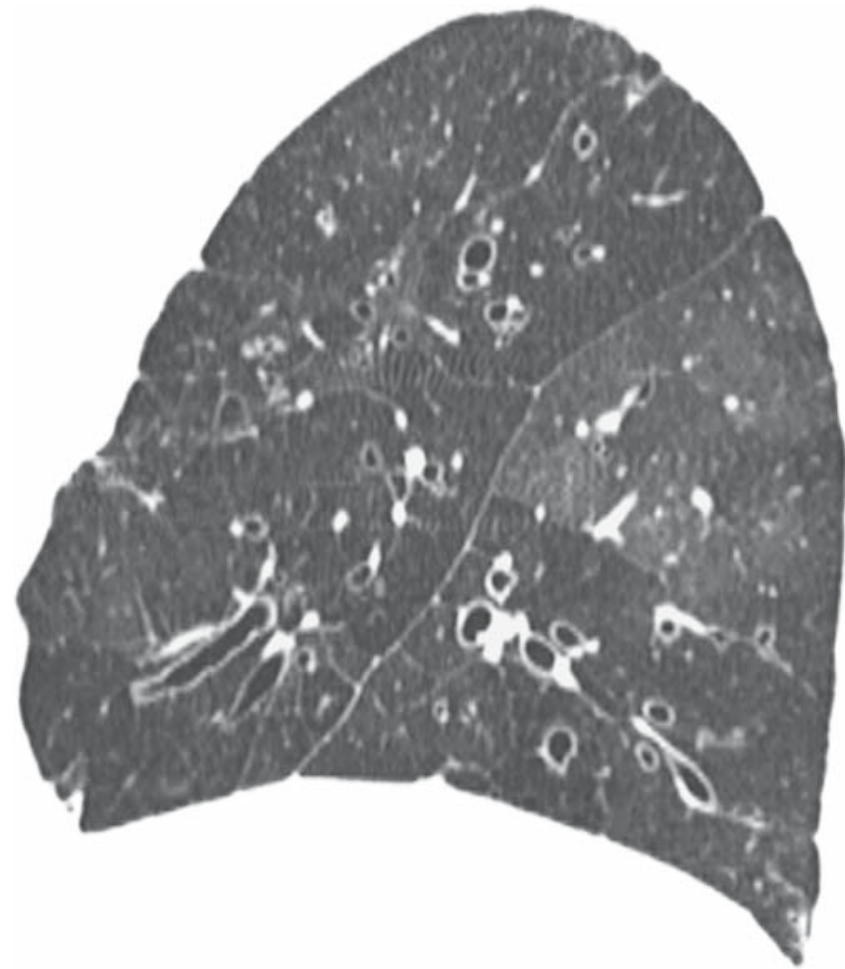

Fig. 9. Ancillary CT findings of obliterative bronchiolitis. Cross-sectional (A) and sagittal (B) reformatted high-resolution CT images obtained on multidetector CT scanner show diffuse areas of decreased attenuation and vascularity with associated cylindrical and varicose bronchiectasis and bronchial wall thickening. The patient was a 21-year-old woman with severe airflow obstruction and obliterative bronchiolitis 8 years after lung transplantation for cystic fibrosis. 


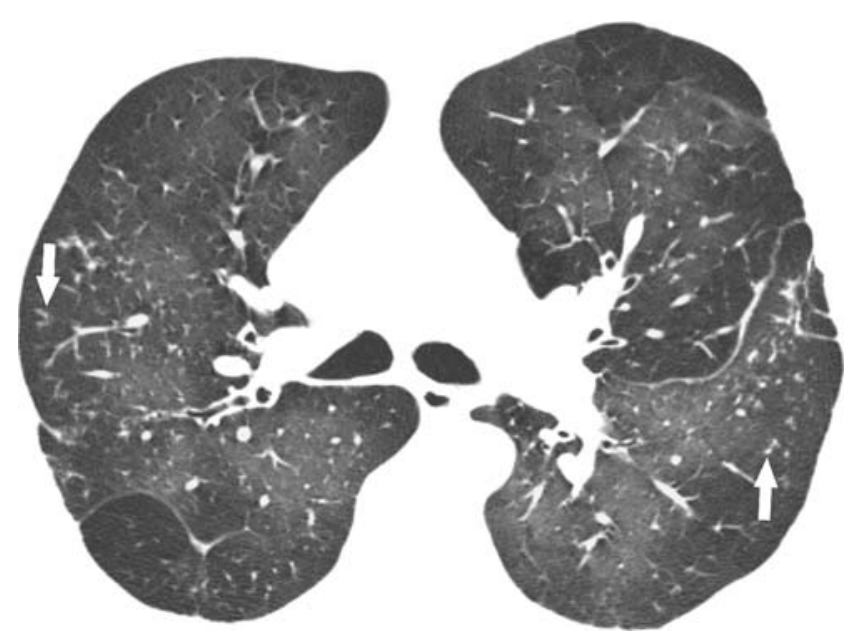

Fig. 10. Obliterative bronchiolitis. High-resolution CT image shows mosaic perfusion pattern and centrilobular nodules and tree-in-bud opacities (arrows) representing thick-walled bronchioles with or without intraluminal debris (same patient as Fig. 5).

Mosaic perfusion can be seen in various airway diseases including $\mathrm{OB}$, asthma, and bronchiectasis; in occlusive pulmonary vascular disease (particularly chronic pulmonary thromboembolism) (Fig.111); and infiltrative lung disease, such as hypersensitivity pneumonitis 45, 52, 63, 66). The differential diagnosis requires careful analysis of associated findings such as bronchial dilatation and enlargement of the main pulmonary artery and interpretation of the CT images in the proper clinical context. Airway diseases that cause mosaic perfusion can usually be distinguished from vascular causes such as chronic pulmonary thromboembolism by the presence of bronchial dilatation, seen in more than $70 \%$ of patients with airway abnormalities, and the lack of enlargement of the main pulmonary artery, a finding seen in the majority of patients with chronic pulmonary thromboembolism associated with mosaic perfusion (45). It should be noted however that bronchial dilatation may also occur
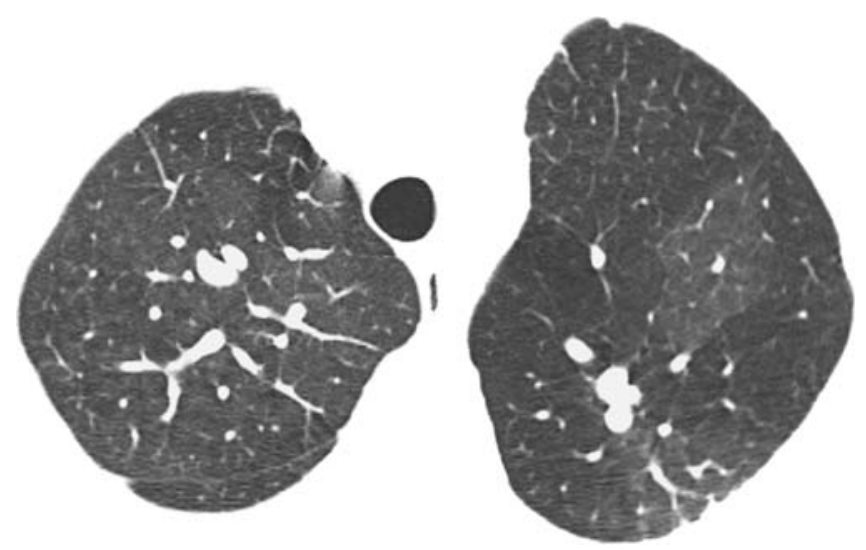

Fig. 11. Mosaic perfusion pattern in chronic pulmonary thromboembolism. High-resolution CT image shows mosaic perfusion in the upper lobes with enlargement of the segmental arteries in areas of increased attenuation. The patient was a 57-year-old woman with chronic thromboembolic pulmonary arterial hypertension. 
in patients with chronic pulmonary thromboembolism 67), and there are no reliable distinguishing features between mosaic perfusion resulting from $\mathrm{OB}$ and mosaic perfusion because of other airway diseases. Furthermore, air trapping can also be seen in patients with pulmonary embolism. In a study by Arakawa et al. (68), air trapping at expiratory images was identified in 9 of 15 (60\%) patients with pulmonary embolism, including four with acute pulmonary embolism, one with chronic pulmonary embolism, and four with acute and chronic pulmonary embolism.

Air trapping is frequently seen in asymptomatic subjects with normal pulmonary function 48 6973) particularly in older subjects and smokers (Fig. 12 70,73, 74). Lobular air trapping involving fewer than three adjacent secondary pulmonary lobules (48) can be seen in approximately $50 \%$ of asymptomatic subjects and in various clinical settings, including OB, cigarette smoking, asthma, bronchiolitis associated with hypersensitivity pneumonitis (Fig. 13), and sarcoidosis 6466 73 75 77). Extent of air trapping, not simply its presence, therefore needs to be taken into account in the interpretation of expiratory CT scans 48,73 ). It has been shown that mosaic perfusion and air trapping can be considered abnormal when they affect an area of more than $25 \%$ of the total area of the lung 48,73 ) and are not limited to the superior segment of the lower lobe or the lingula tip (48). The presence of additional CT features in areas of decreased attenuation is also valuable in differentiating between abnormal air trapping in patients with OB and normal subjects. In a review of the high-resolution CT findings of 15 patients with pathologically proven OB after lung transplantation and 18 control subjects, the combination of bronchial dilatation on the inspiratory CT scan and air trapping on the expiratory CT scan was seen only in patients with OB and were the two most sensitive and specific findings on high-resolution CT scans of patients with OB (46).

Copley et al. 19) assessed the discriminatory value of high-resolution CT to distinguish between $\mathrm{OB}$, asthma, centrilobular emphysema, panlobular emphysema, and normal controls. A correct firstchoice diagnosis was made in 199 of 276 (72\%) observations, and a correct first-choice diagnosis was made in 35 of $38(92 \%)$ observations in patients with OB. The major sources of diagnostic inaccuracy were difficulty in differentiating between panlobular and centrilobular emphysema, asthma and normality, and asthma and OB. Distinguishing features between OB and panlobular emphysema because of $\alpha_{1}$-antitrypsin deficiency were the presence of parenchymal destruction, vascular distortion,

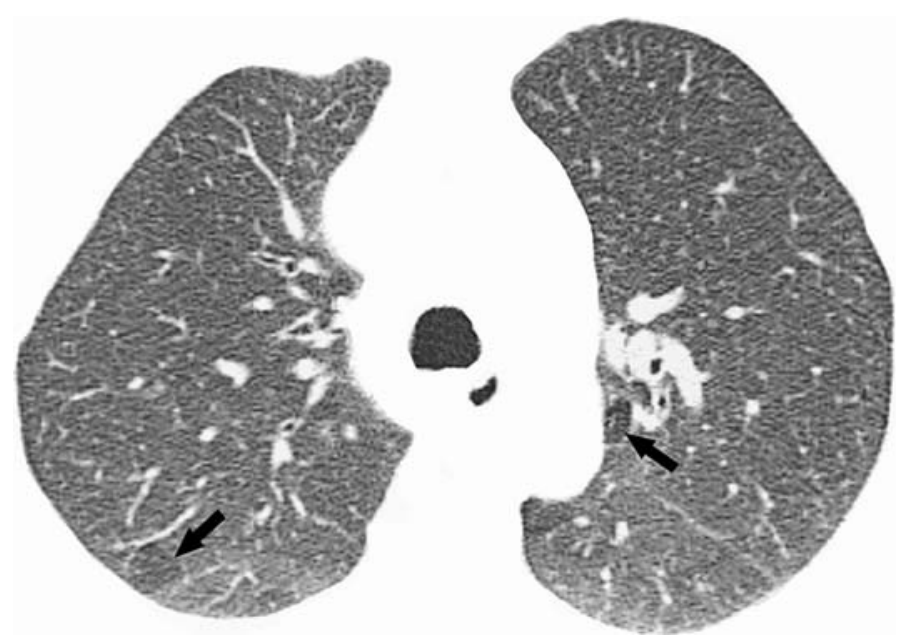

Fig. 12. Normal air trapping on CT. High-resolution CT image at the level of aortic arch obtained at end of maximal expiration shows a few lobular areas of air trapping. The patient was a 56-year-old man with no pulmonary symptoms. 
A)

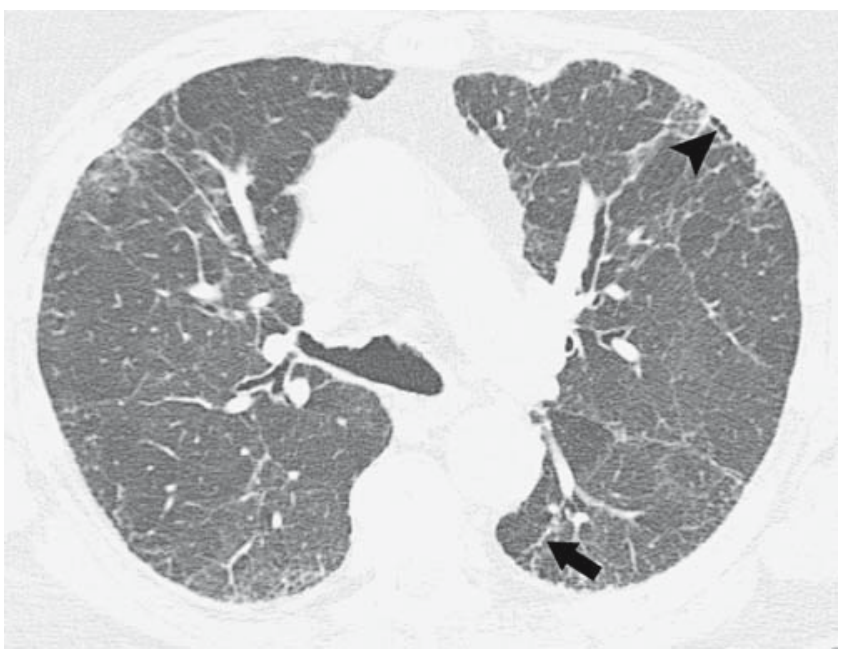

B)

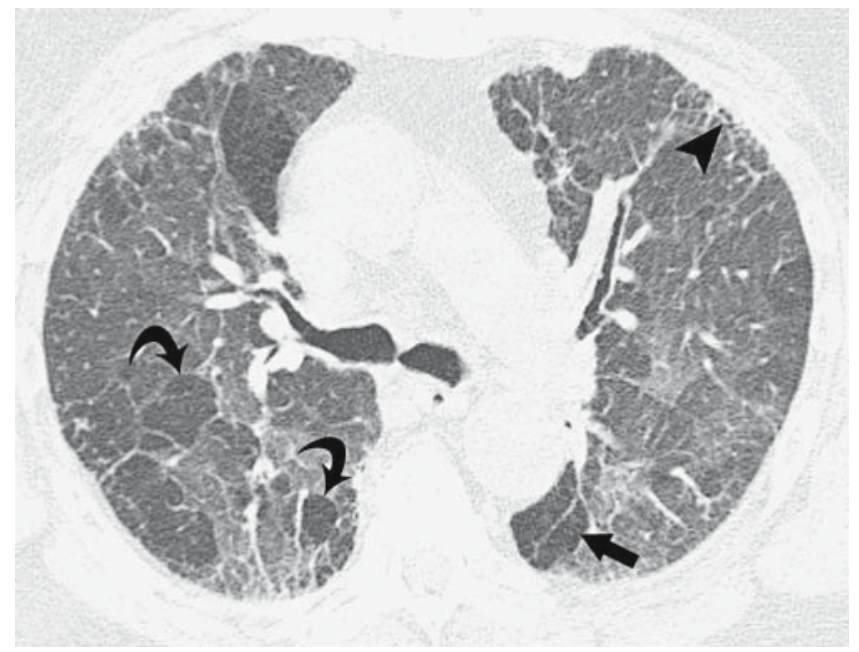

Fig. 13. Lobular air trapping in a 79-year-old man with subacute and chronic hypersensitivity pneumonitis. (A) High-resolution CT image shows bilateral patchy ground-glass opacities, fine reticulation, and mild subpleural honeycombing (arrowhead). Also noted are a few lobules with decreased attenuation and vascularity (straight arrow). (B) Expiratory high-resolution CT scan at the same level as (A) demonstrates air trapping in lobules that had decreased attenuation on the inspiratory CT (straight arrow) and in other lung regions (curved arrows). The lobular areas of air trapping are presumably related to obliterative bronchiolitis and the ground-glass opacities due to interstitial lymphocytic infiltration.

and linear scars or thickened septa at the lung bases in most patients with panlobular emphysema (Fig. 14). Patients with OB were more likely to have bronchial dilatation and decreased parenchymal attenuation and vascularity than asthmatics patients. The authors concluded that high-resolution CT is helpful to distinguish diseases that cause airflow obstruction, and it is particularly accurate in the identification of $\mathrm{OB}(19)$. Jensen et al. (47) compared the CT findings in patients with refractory asthma with those of patients with idiopathic OB. A mosaic pattern of lung attenuation was seen in $50 \%$ of OB patients compared with only $3 \%$ of patients with refractory asthma. 
A)

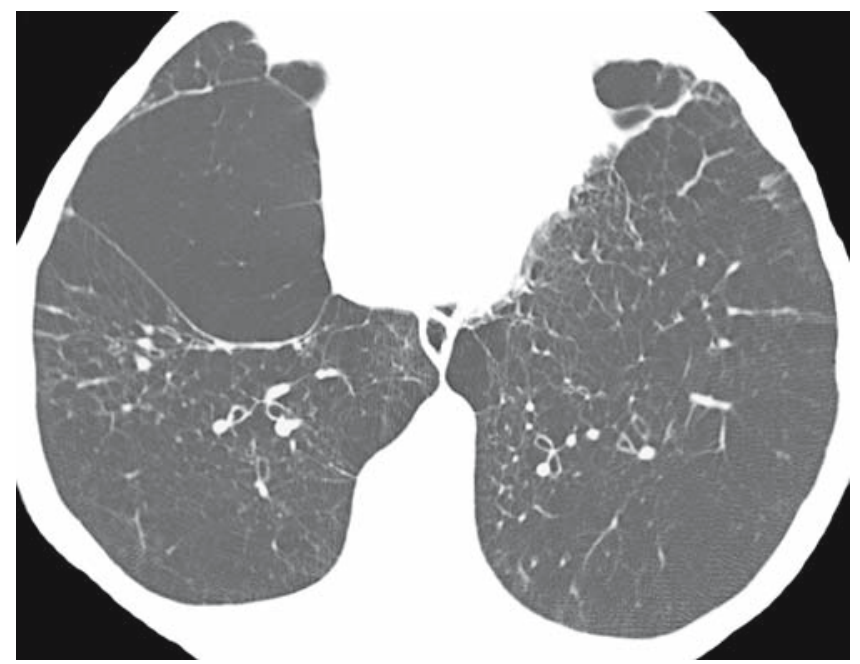

B)

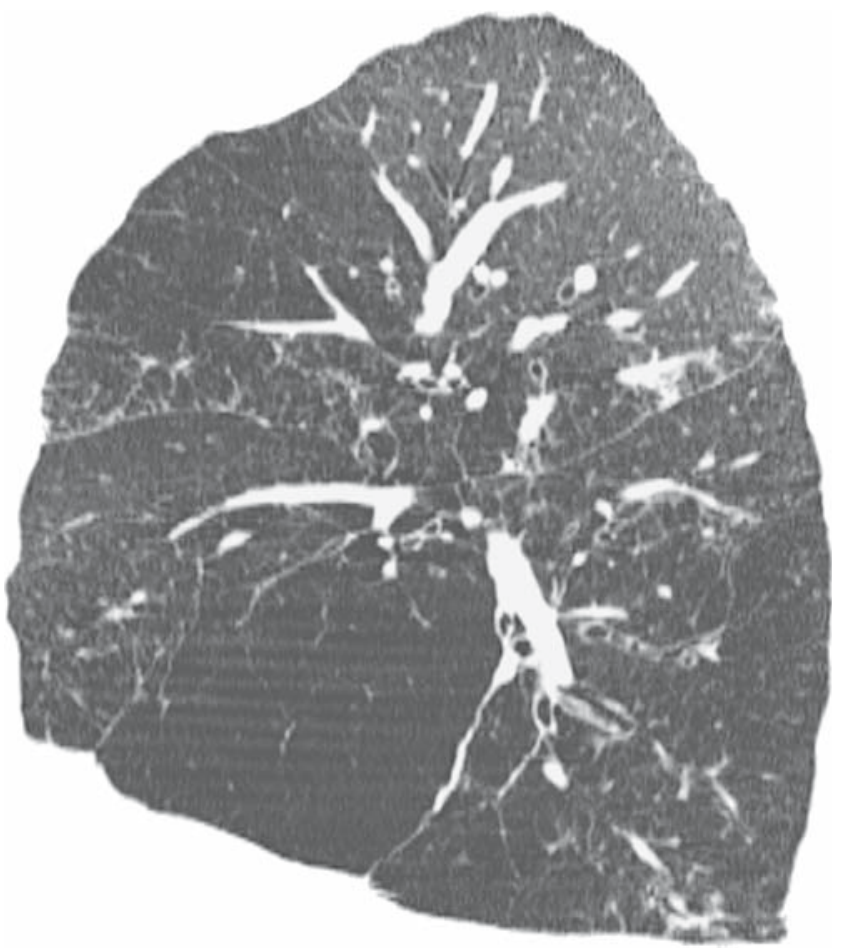

Fig. 14. Severe panlobular emphysema in 53-year-old man with $\alpha_{1}$-antitrypsin deficiency. (A) Highresolution CT image obtained in a multidetector CT scanner shows extensive areas of decreased attenuation with parenchymal destruction, vascular distortion, and linear scars. (B) Sagittal reformatted image shows the predominance of abnormalities in the lower lung regions typical of panlobular emphysema. 


\section{SPECIFIC CAUSES AND UNDERLYING DISEASES ASSOCIATED WITH OBLITERATIVE BRONCHIOLITIS}

A large number of conditions may result in OB (see Table1. The vast majority of cases, however, occur following childhood viral or mycoplasma infection 3.40 .78 ), hematopoietic stem cell or lung and heart-lung transplantation (79, 82, and toxic fume inhalation (3,5, 83,). Less common causes include connective tissue disorders (especially rheumatoid arthritis) 8490), drug therapy including D-penicillamine, lamustine and gold (5,91), ingestion of toxines such as Sauropous androgyn 9294), neuroendocrine cell hyperplasia with multiple carcinoid tumorlets 9597 ), inflammatory bowel disease 98. 99, , eosinophilic fasciitis (3.5), Stevens-Johnson syndrome and paraneoplastic pemphigus 100 101). OB may be seen as a component of interstitial lung disease (hypersensitivity pneumonitis and sarcoidosis) 64 75, 76) or large airway disease (asthma, bronchiectasis, and cystic fibrosis) 102 105). Rarely OB may be idiopathic (100).

\subsection{Postinfectious Obliterative Bronchiolitis}

Obliterative bronchiolitis may be a late sequela of lower respiratory tract infections occurring in infancy or childhood, particularly by adenovirus 40,107 , 108). Other causes include respiratory syncytial virus, parainfluenza virus, influenza virus, measles, and Mycoplasma pneumoniae (5, 109). The true prevalence of $\mathrm{OB}$ due to infection is unknown; however, it has been estimated that approximately $1 \%$ of the patients with acute viral bronchiolitis develop postinfectious OB (11d). The diagnosis of postinfectious $\mathrm{OB}$ in the childhood is based on history of lower airway infection, usually acute viral bronchiolitis, followed by persistent chronic obstructive pulmonary disease. The time interval between the acute illness and the development of postinfectious OB is generally 6 months (range 1-42 months) (111). In the majority of the cases, the condition does not become apparent until adulthood. Most patients with postinfectious $\mathrm{OB}$ are asymptomatic or present with mild-to-moderate clinical findings and have a good prognosis $40,78,112$ ). Occasionally, severe and sometimes fatal disease may occur 112 113 ). In a prospective study performed to define the clinical course and the prognosis of 31 patients who had symptomatic postinfectious OB during a mean of 3.5 years of follow-up, clinical remission was identified in $23 \%$ of the patients, persistence of respiratory symptoms in $68 \%$, and death in approximately $10 \%$ (112). Lung transplantation or lung volume reduction surgery should be considered for patients who show persistent and severe obstructive symptoms and progressive impairment in lung function 114). The chest radiograph may be normal or show various findings including unilateral hyperlucency of a lobe or lung; bilateral hyperlucent lungs; complete collapse of the affected lobe; a mixed pattern of hyperlucency and persistent collapse; and peribronchial thickening 78 ). High-resolution CT usually demonstrates bronchial wall thickening, bronchiectasis, mosaic perfusion, and air trapping (see Figs 7 and 15, 109, 115).

Swyer-James (MacLeod) syndrome is an uncommon condition characterized radiographically by a hyperlucent lobe or lung and functionally by normal or reduced TLC and presence of expiratory air trapping. The hyperlucency of the lobe or lung results from decreased pulmonary blood flow secondary to OB. Swyer-James syndrome typically follows lower respiratory tract infection in a developing lung, most commonly adenovirus bronchiolitis or bronchopneumonia. The pulmonary tissue and pulmonary vasculature are hypoplastic. The chest radiograph performed at TLC shows hyperlucency and decreased vascularity of the involved lobe or lung, normal or decreased size of the involved lobe or lung, and decreased size of the ipsilateral hilum (Fig. 16). Expiratory chest radiograph shows air trapping in the involved lobe or lung.

High-resolution CT, similar to the radiograph, shows hyperlucency and decreased vascularity and normal or decreased size of the involved lung or lobe on inspiratory images and air trapping on expiratory images 116 118). In the vast majority of cases, CT demonstrates bronchiectasis and areas of abnormally low attenuation and perfusion and air trapping in the contralateral lung (Fig. 17) 

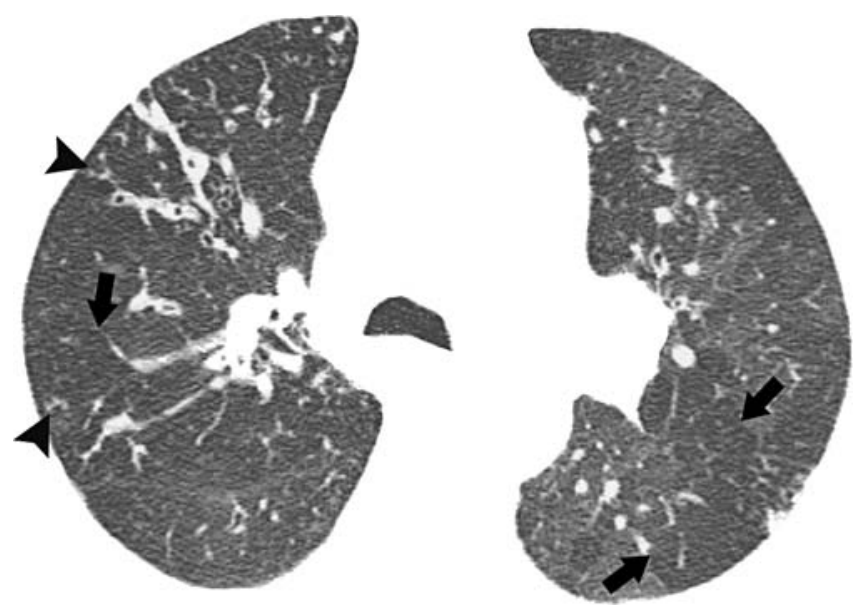

Fig. 15. Obliterative bronchiolitis in 41-year-old man with history of repeated childhood respiratory tract infections. High-resolution CT image shows areas of decreased attenuation and vascularity (straight arrows) interspersed with areas of increased attenuation because of blood flow redistribution (mosaic perfusion pattern), particularly in the left upper lobe. Also noted are bronchial wall thickening and a few centrilobular nodules and tree-in-bud opacities (arrowheads).

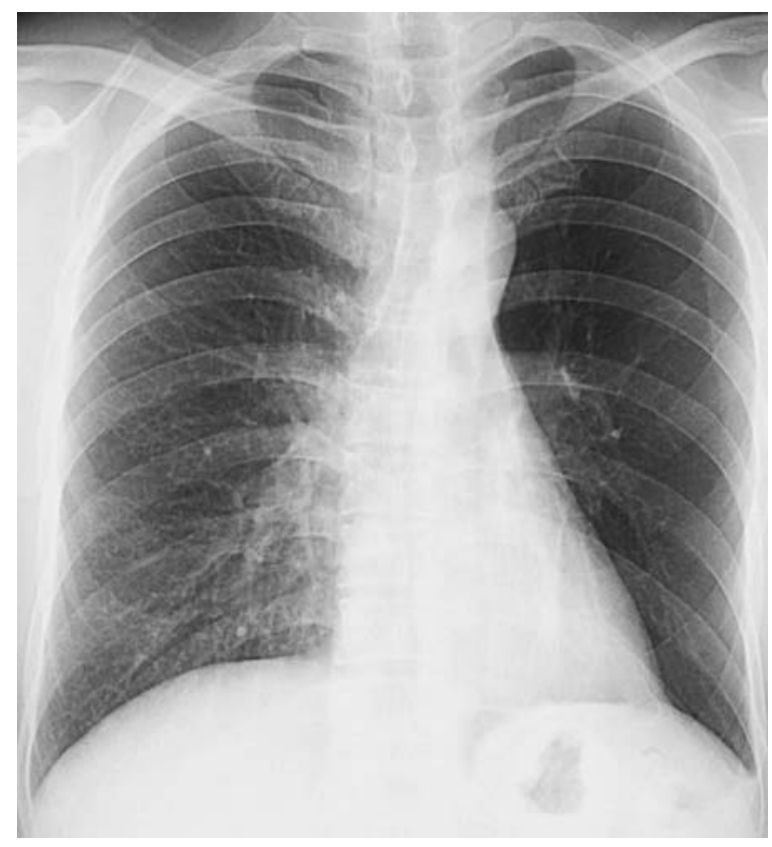

Fig. 16. Swyer-James (MacLeod) syndrome. Posteroanterior chest radiography shows hyperlucency, decreased vascularity, and decreased volume of the left lung with ipsilateral mediastinal shift. The patient was an asymptomatic 40-year-old man with obliterative bronchiolitis following childhood viral infection. 


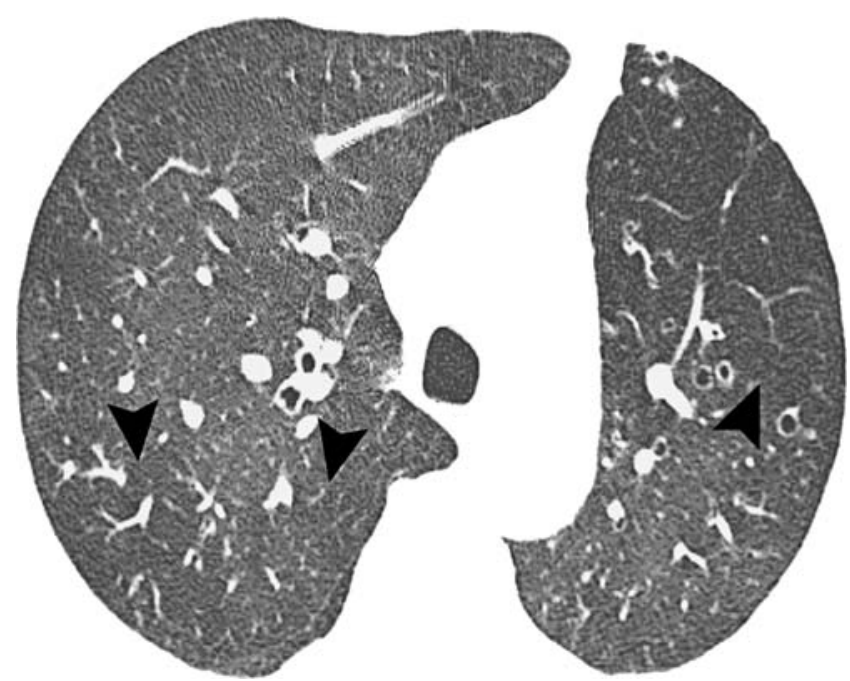

Fig. 17. Swyer-James (Macleod's) syndrome. High-resolution CT image demonstrates extensive areas of decreased attenuation and vascularity in the left upper lobe and to lesser extent in the right upper lobe (arrowheads). Also noted are decreased volume of the left lung and left upper lobe bronchiectasis.

116.117). Air trapping is seen on CT performed at end-expiration and on dynamic expiratory CT 119). The majority of patients with Swyer-James syndrome are asymptomatic adults. Occasionally, patients may present with a history of repeated lower respiratory tract infections or shortness of breath.

\subsection{Obliterative Bronchiolitis Associated with Transplantation}

Obliterative bronchiolitis is a common and important complication of lung and heart-lung transplantation and remains the single leading cause of morbidity and mortality in these patients. The prevalence of OB following lung transplantation is approximately $20 \%$ at 1 year and greater than $50 \%$ at 3-5 years $79-120-123)$. OB is the primary cause of death in $30 \%$ of the affected individuals after the third postoperative year and more than half of affected individuals after 5 years $120,121,123,124)$. Clinically, OB typically is first recognized 16-20 months after transplantation although it may manifest as early as the second or third month after transplantation $80,125,126$ ). OB is believed to be a manifestation of chronic rejection. Although by definition OB is a pathologic diagnosis, histologic confirmation is difficult to obtain. The reported sensitivity of transbronchial biopsy ranges from 15 to $87 \%$ and the specificity approximately $75 \%, 21,23,25,26$. Surgical biopsy is seldom performed on these patients. Bronchoalveolar lavage is usually nonspecific and may show neutrophilic and/or lymphocytic inflammation (127 128). However, transbronchial biopsy and bronchoalveolar lavage are important in excluding other possible diagnoses as contributing causes of deteriorating pulmonary function in patients with lung transplantation and heart-lung transplantation, such as acute rejection and infection 129 13d). Because of the low sensitivity of transbronchial biopsy in demonstrating OB, the International Society for Heart and Lung Transplantation has established the concept of bronchiolitis obliterans syndrome (BOS) and a staging system to quantify the severity of airflow obstruction 131). According to the revised classification system, the staging is based on the reduction in the forced expiration volume in $1 \mathrm{~s}\left(\mathrm{FEV}_{1}\right)$ and mid-expiratory flow rate $\left(\mathrm{FEF}_{25-75}\right)$, in comparison with baseline post-transplant values, with or without histologic documentation of $\mathrm{OB}$, and the exclusion of other causes for the functional abnormality (132). On the basis of the severity of functional 
impairment, BOS can be subdivided into five different categories: $\mathrm{BOS} 0\left(\mathrm{FEV}_{1}>90 \%\right.$ of baseline, and $\mathrm{FEF}_{25-75}>75 \%$ of baseline), BOS 0-p (potential OB; $\mathrm{FEV}_{1} 81-90 \%$ of baseline, and/or $\mathrm{FEF}_{25-75}$ $\leq 75 \%$ of baseline), BOS 1 (mild OB; $\mathrm{FEV}_{1}$ 66-80\% of baseline), BOS 2 (moderate OB; FEV 1 $51-65 \%$ of baseline), and $\mathrm{BOS} 3$ (severe $\mathrm{OB} ; \mathrm{FEV}_{1} \leq 50 \%$ of baseline).

Post-transplant $\mathrm{OB}$ has a variable course. Some patients experience a sudden onset with rapid decline of lung function and respiratory failure. Others experience insidious onset with a slow, progressive decline over time or, less commonly, an initial rapid decline in $\mathrm{FEV}_{1}$ followed by a prolonged period of stability 133 134). Clinical symptoms at onset are usually absent or nonspecific. Some patients present with an asymptomatic fall in $\mathrm{FEV}_{1}$ and/or biopsy findings of OB. Clinical symptoms include malaise, dry cough, and shortness of breath on exertion. Sputum production at presentation is typically absent; however, repeated episodes of bacterial infection, followed by permanent airway colonization with pathogenic bacteria and fungi (e.g., Pseudomonas and Staphylococcus spp. and Aspergillus fumigatus), may result in productive cough later in the course of the disease 134).

Obliterative bronchiolitis is also the most common noninfectious late pulmonary complication of allogeneic hematopoietic stem-cell transplantation (HSCT) 127 135). OB in these patients typically occurs more than 3 months following transplantation and in the setting of underlying chronic graftversus-host disease (GVHD) 82 127). OB is estimated to affect approximately $20 \%$ of patients who receive allogeneic transplants 81 82) but is rare after autologous transplantation (136). In a recent study, the 5-year survival rate of 47 HSCT recipients with OB was $10 \%$, compared with $40 \%$ for those without $\mathrm{OB}$ (137). Occasionally, air-leak syndromes including pneumomediastinum, pneumothorax, pneumopericardium, subcutaneous emphysema, and cervical emphysema may complicate severe OB in these patients 17,138 .

The pathogenesis of $\mathrm{OB}$ in lung transplantation and heart-lung transplantation is not well understood. The main risk factors for the development of BOS are acute rejection, particularly when recurrent or severe, lymphocytic bronchitis/bronchiolitis, and cytomegalovirus pneumonitis 132 134 141 144). Gastroesophageal reflux with occult microaspiration that may promote chronic inflammation and bacterial infections in the lower airways may be a potential risk factor for BOS 145.146). The etiology of post-transplant gastroesophageal reflux is probable multifactorial and includes intraoperative vagal injury, drug-induced prolonged gastric emptying, and impaired lower esophageal sphincter function 145,148 . Preliminary studies suggest that antireflux surgery, such as fundoplication, may improve lung function in some of these patients (149). Risk factors for OB among allogeneic recipients are probably also multifactorial and include acute and chronic GVHD, older donor and recipient age, myeloablative conditioning, methotrexate use, antecedent respiratory infection, and serum immunoglobulin deficiency $81,82,150$ ).

Early diagnosis of $\mathrm{OB}$ in transplanted patients is important because prompt initiation of therapy may help to preserve lung function and improve long-term survival 81,134 ). The treatment of OB usually consists of corticosteroids and augmented immunosuppression. However, only a minority improve. BOS does not appear to recur in an accelerated manner after retransplantation 151 153). The risk of developing $\mathrm{OB}$ is similar to that of first-time lung transplant recipients.

Lung function is currently the gold standard for detecting chronic allograft dysfunction in transplanted patients. High-resolution CT is a valuable tool in the evaluation and follow-up of transplanted patients (Fig. 18). CT is a direct measure of the lung structure and allows the identification of structural abnormalities associated with chronic allograft dysfunction, including bronchiectasis, airway wall thickening, mucus in small and large airways, and air trapping because of small airway abnormalities (see Figs 8 and 9. The presence of air trapping on expiratory high-resolution CT scans is the most sensitive and accurate radiologic indicator of $\mathrm{OB}$ following transplantation 46154158 ). High-resolution CT has been used to predict BOS in both adults and children; however, more recent studies have shown that the value of air trapping at expiratory high-resolution CT before the clinical 
A)

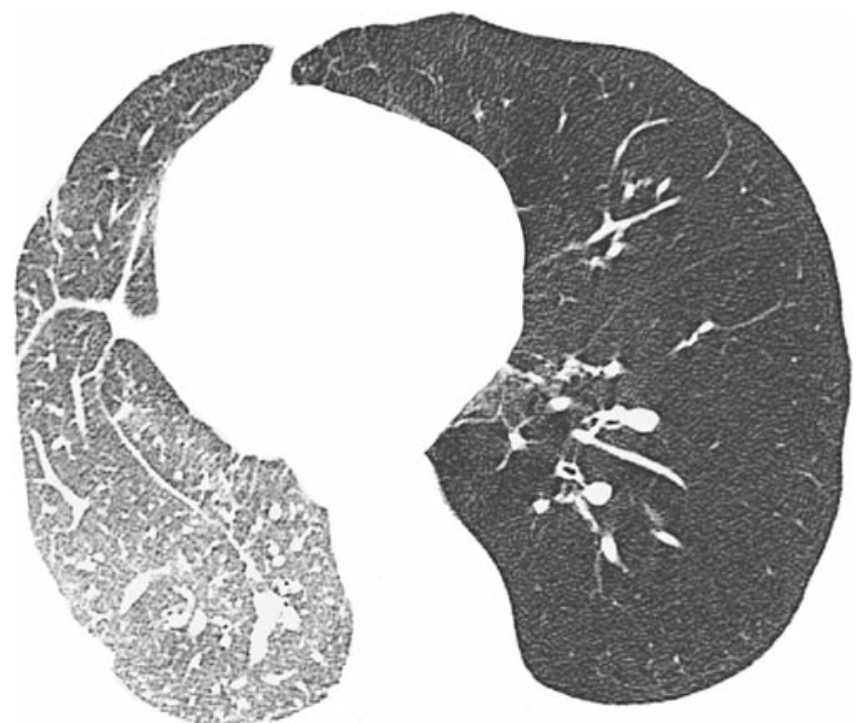

B)

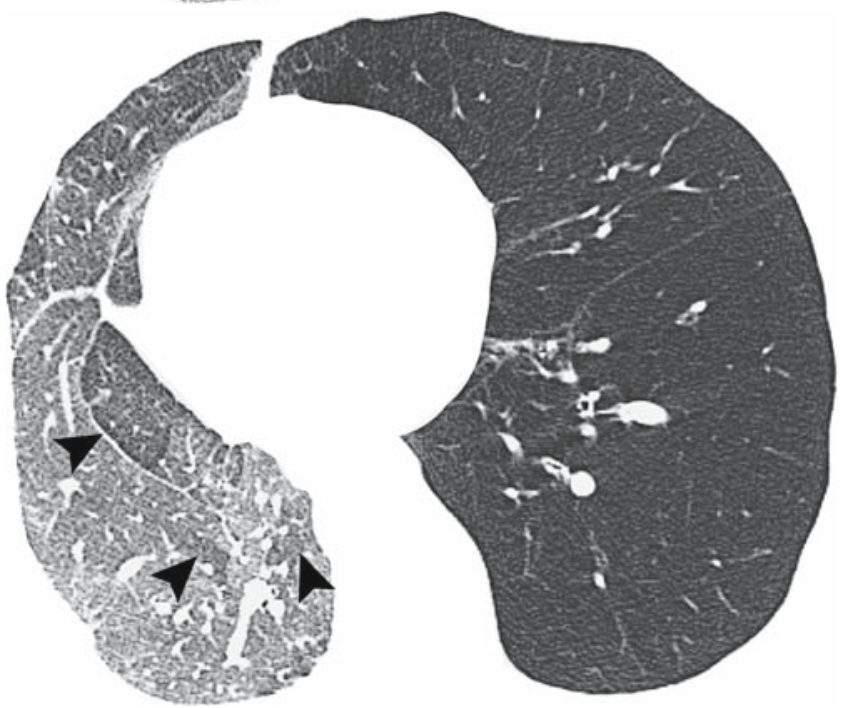

Fig. 18. Obliterative bronchiolitis following unilateral lung transplantation for severe panacinar emphysema. (A) Expiratory high-resolution CT image shortly after transplantation shows no definite abnormality in the transplanted lung. The native lung demonstrates diffuse decrease in attenuation and marked hyperinflation due to panacinar emphysema. (B) Expiratory image at the same level as (A) 1 year later demonstrates lobular air trapping in the right lower lobe (arrows). The patient was a 60-year-old man with bronchiolitis obliterans syndrome.

appearance and during the early stages of BOS is lower than previously reported 154, 156). The reported sensitivities and specificities of air trapping range from 44 to $91 \%$ and 80 to $100 \%$, respectively 46154158 ). This variability may be due to differences in the technique used to quantify the extent of air trapping, patient selection with inclusion of heart-lung or bilateral-lung and single-lung transplant recipients and predate the revised criteria for BOS, which are believed to be more sensitive for the detection of early-stage BOS 132). Furthermore, most studies included high-resolution CT scans that were obtained after clinical diagnosis of OB. In a recent study, Konen et al. (154) assessed 
the value of CT findings in predicting BOS before its clinical appearance and during the early stages of BOS. The authors found lower sensitivity for air trapping (44-50\%) than previously reported (74-91\%) 155 158). The sensitivities of mosaic perfusion, bronchiectasis, and bronchial wall thickening were even lower, not exceeding 25\% 154 158 159). The limitations of high-resolution CT are also at least in part because of the inter- and intra-observer variability in the interpretation of the CT images and the different scoring systems used to quantify the extent of air trapping on CT 15. 156 157 160 . A composite CT score system may have a potential role in the early detection of OB in lung transplant recipients, as demonstrated in a recent study with good intra- and inter-observer agreement (161). Preliminary studies have shown that functional MR imaging using hyperpolarized 3-He detects BOS earlier than spirometry or high-resolution CT 31, 162). The main limitations of functional MR imaging are high cost and limited availability. It therefore currently remains an investigational modality.

\subsection{Postinhalational Obliterative Bronchiolitis}

Obliterative bronchiolitis is a well-described complication of inhalational injury being seen most commonly after inhalation of nitrogen dioxide (Silo filler's disease). The acute phase of Silo filler's disease typically manifests within minutes or hours after exposure and usually resolves within hours 83). The main clinical symptoms consist of cough, dyspnea, fatigue, and cyanosis. Patients may develop pulmonary edema and acute respiratory distress syndrome (ARDS). If the patient survives, a progressive and irreversible obstructive ventilatory defect may be noted 2-5 weeks later (83). At the late stage, the radiologic findings are similar to those of OB because of other causes. Other toxic gases associated with OB include ammonia, chlorine, hydrogen bromide, hydrogen selenide, sulfur dioxide, and fire smoke (3,5). Recently, diacetyl (2,3-butanedione), a ketone with butter-flavor characteristics, was the predominant compound isolated in workers in a microwave popcorn plant 163 164), who developed clinical, histologic, and imaging findings of OB 163). Some of these patients developed severe symptoms and required lung transplantation.

\subsection{Obliterative Bronchiolitis Associated with Connective Tissue Disorders}

Several connective tissue diseases are associated with an increased risk of bronchiolitis, but OB is seen most commonly in patients with rheumatoid arthritis $84.85,87.165$ [166). OB in rheumatoid arthritis usually occurs in patients with long-standing disease and is seen most commonly in women in their fifth to sixth decades of life 8485 ). $\mathrm{OB}$ as the sole and presenting feature of rheumatoid arthritis is rare 86, 167).

The course of disease is variable. Penicillamine therapy and, less commonly, gold therapy have been implicated as potential contributive causative agents of $\mathrm{OB}$ in some patients with rheumatoid arthritis 167 169).

The radiologic findings of rheumatoid arthritis associated with OB are similar to those of patients with others forms of OB. The most common high-resolution CT findings are mosaic perfusion, air trapping, and bronchiectasis (Fig. 19, 86, 170, 171).

Occasionally, OB may be seen in association with connective disorders other than rheumatoid arthritis, including Sjögren's syndrome 172), systemic lupus erythematosus 173), and scleroderma 88 (9).

\subsection{Sauropous androgynus-Related Obliterative Bronchiolitis}

Consumption of juice prepared from the uncooked leaves of the vegetable Sauropous androgynus (a member of the Euphorbiaceae family), which is alleged to help weight control, has a known association with $\mathrm{OB}$ 92 94 174). S. androgynus is commonly found in Malaysia, Indonesia, southwest China, and Vietnam. It is not known whether OB results from cytotoxic effect, inflammatory reaction, 
A)

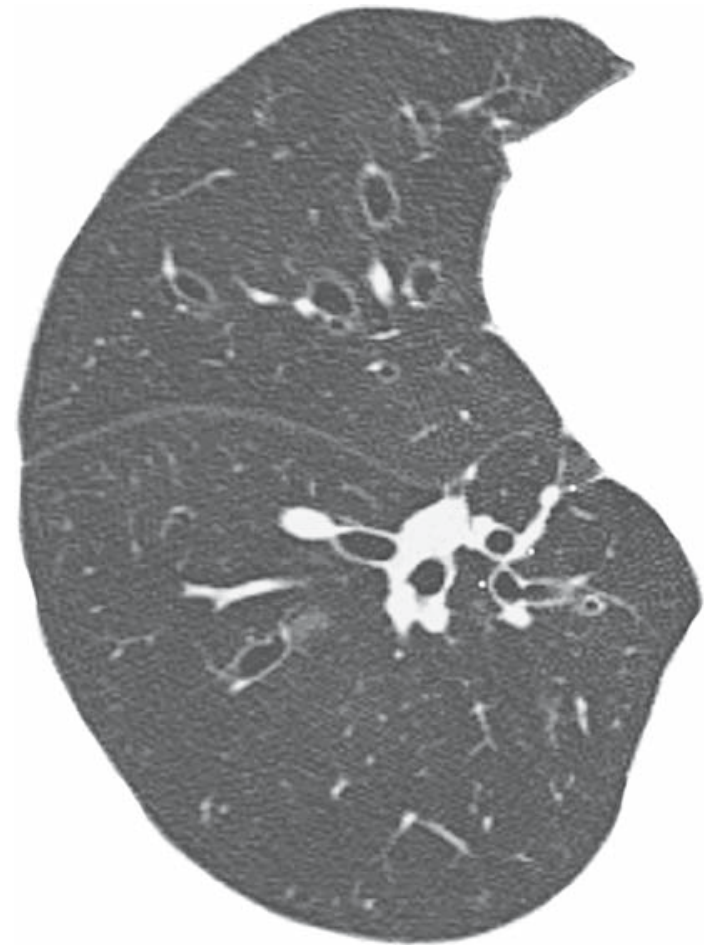

B)

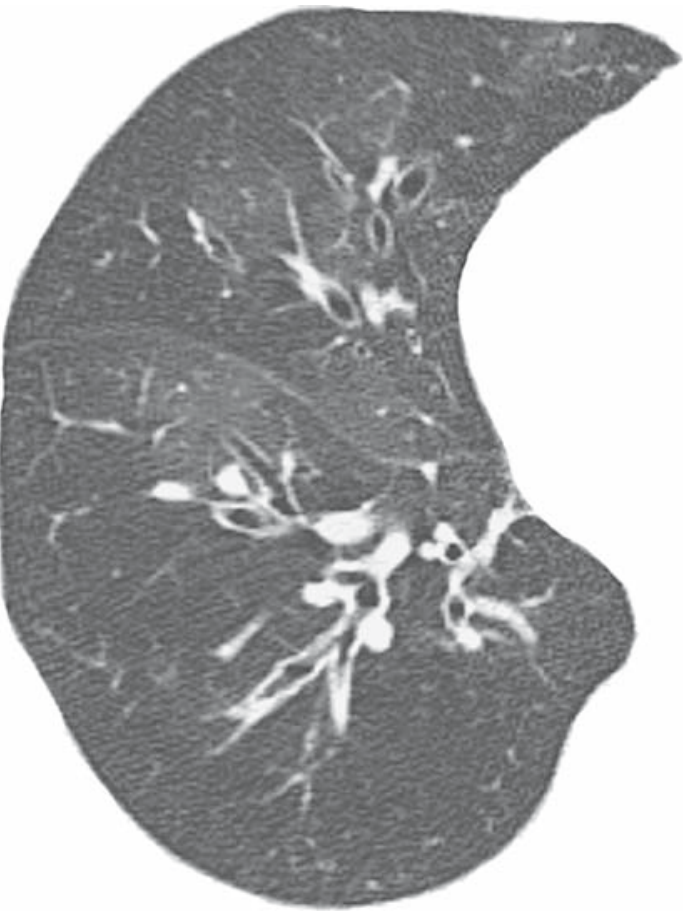

Fig. 19. Obliterative bronchiolitis in a 49-year-old woman with long-standing rheumatoid arthritis. (A) Highresolution CT image targeted to the right lung shows extensive areas of decreased attenuation and vascularity and bronchiectasis. (B) Expiratory image shows air trapping. 
or immunological response. Lai et al. (94) reported the clinical and radiologic features of OB associated with consumption of uncooked $S$. androgynus in 23 patients during an outbreak in Taiwan. All patients were young or middle-aged nonsmoking women who developed rapidly progressive shortness of breath and persistent cough 3-4 months after ingestion of blended vegetable juice. The patients had moderate-to-severe airflow obstruction without response to bronchodilator therapy or prednisolone. The chest radiographs were normal, and high-resolution CT demonstrated bilateral bronchiectasis and patchy mosaic perfusion at inspiratory CT in 11 of 23 patients and air trapping at expiratory scans in all patients. Four patients had open lung biopsy findings of OB. OB associated with consumption of $S$. androgynus has a poor prognosis, some patients requiring lung transplantation (175. 176 ).

\subsection{Obliterative Bronchiolitis Associated with Diffuse Neuroendocrine Cell Hyperplasia, Carcinoid Tumorlets, and Carcinoid Tumors}

Neuroendocrine (Kulchitzky) cells are commonly found in the basal layer of the surface epithelium and in the bronchial glands from the level of the main bronchi to the proximal bronchioles. Diffuse idiopathic pulmonary neuroendocrine cell hyperplasia (DIPNECH) is a rare condition characterized by proliferation of neuroendocrine cells as clusters of cells or as linear arrays along the basement membrane 95. 177). DIPNECH is regarded as a precursor to the development of carcinoid tumorlets, which consist of nodular proliferations (diameter $<5 \mathrm{~mm}$ ) of airway neuroendocrine cells that extend beyond the epithelium into the adjacent wall or lung parenchyma. If such a lesion exceeds $5 \mathrm{~mm}$ in diameter, it is regarded as a carcinoid tumor (177 179). Aguayo et al. (95) reported the clinical and pathologic findings of six lifelong nonsmokers who had diffuse hyperplasia of airway neuroendocrine cells and multiple pulmonary carcinoid tumorlets associated with $\mathrm{OB}$ and airway obstruction. The $\mathrm{OB}$ in these patients is postulated to be secondary to a combination of intraluminal obstruction by hyperplastic neuroendocrine cells and peribronchiolar fibrosis presumably secondary to peptide secretory products released by the proliferating neuroendocrine cells 95,180 ). The patients are usually women in their fifth or sixth decade and have history of long-standing progressive respiratory distress $(>10$ years) and persistent cough with mild-to-moderate airflow obstruction at lung function tests 96). The chest radiograph is usually normal. The most common high-resolution CT findings are mosaic perfusion at inspiratory CT and air trapping at expiratory images. Other high-resolution CT findings include bronchial wall thickening, a few dilated bronchi and occasional well-defined nodules measuring $0.2-1.5 \mathrm{~mm}$ in diameter that correspond to the carcinoid tumorlets and carcinoid tumors identified histologically (Fig. 20, 96, 178, 181).

\subsection{Cryptogenic Obliterative Bronchiolitis}

Cryptogenic (idiopathic) OB is rare and has been described mainly in older women 106, 182). Patients with cryptogenic OB usually present with chronic cough, dyspnea, mild-to-severe airway obstruction that may progress to respiratory failure and does not respond to bronchodilators. The radiologic findings of cryptogenic $\mathrm{OB}$ are similar to those of patients with other forms of $\mathrm{OB}$ (see Fig. 6) 35 47).

\subsection{Obliterative Bronchiolitis Associated with Inflammatory Bowel Disease}

The most frequent pulmonary complications associated with inflammatory bowel disease are tracheobronchitis, chronic bronchitis, and bronchiectasis $183-186$. Occasionally, patients with ulcerative colitis and Crohn's disease may develop OB (187). Colectomy is believed to be a risk factor for the development of pulmonary disease in these patients 99 183 184 186). In a study of 17 patients with inflammatory bowel disease (14 patients with ulcerative colitis and three patients with 

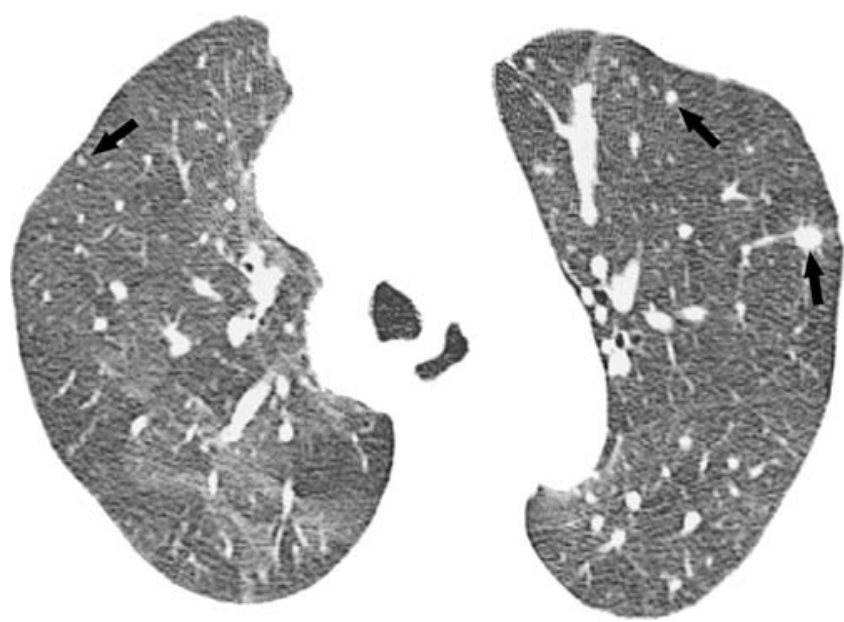

Fig. 20. Diffuse idiopathic pulmonary neuroendocrine cell hyperplasia (DIPNECH). Expiratory highresolution CT image at the level or aortic arch shows patchy areas of air trapping and bilateral 2-8 mm well-defined soft tissue nodules (arrows). The patient was a 72-year-old woman with biopsy proven obliterative bronchiolitis and DIPNECH and multiple pulmonary carcinoid tumorlets and carcinoid tumors.

Crohn's disease) without active bowel disease at the time of the study, bronchiectasis was seen in 13 patients $(76 \%)$ including 11 with ulcerative colitis and two with Crohn's disease, nine patients showed evidence of air trapping, and five had tree-in-bud opacities at high-resolution CT 99).

\section{REFERENCES}

1. Colby TV. Bronchiolitis. Pathologic considerations. Am J Clin Pathol 1998; 109:101-109.

2. Myers JL, Colby TV. Pathologic manifestations of bronchiolitis, constrictive bronchiolitis, cryptogenic organizing pneumonia and diffuse panbronchiolitis. Clin Chest Med 1993; 14:611-623.

3. Ryu JH, Myers JL, Swensen SJ. Bronchiolar disorders. Am J Respir Crit Care Med 2003; 168:1277-1292.

4. King TE. Overview of bronchiolitis. Clin Chest Med 1993; 14:607-610.

5. Travis WD, Colby TV, Koss MN, Rosado-de-Christenson ML, Muller NL, King TE, Jr., eds Bronchiolar disorders. In: Atlas of Nontumor Pathology. Non-Neoplastic Disorders of the Lower Respiratory Tract. Washington, DC: American Registry of Pathology and the Armed Forces Institute of Pathology, 2002; 351-380.

6. Muller NL, Miller RR. Diseases of the bronchioles: CT and histopathologic findings. Radiology 1995; 196:3-12.

7. Poletti V, Costabel U. Bronchiolar disorders: classification and diagnostic approach. Semin Respir Crit Care Med 2003; 24:457-464.

8. Padley SPG, Adler BD, Hansell DM, Müller NL. Bronchiolitis obliterans: high-resolution CT findings and correlation with pulmonary function tests. Clin Radiol 1993; 47:236-240.

9. Gosink BB, Friedman PJ, Liebow AA. Bronchiolitis obliterans: roentgenographic-pathologic correlation. AJR Am J Roentgenol 1973; 117:816-832.

10. Baar HS, Galindo J. Bronchiolitis fibrosa obliterans. Thorax 1966; 21:209-214.

11. Lange W. Ueber eine eigenthumliche Erkrankung der kleinen Bronchien und Bronchiolen (Bronchitis et bronchiolitis obliterans). Dtsch Arch Klin Med 1901; 70:342-364.

12. American Thoracic Society/European Respiratory Society International Multidisciplinary Consensus Classification of the Idiopathic Interstitial Pneumonias. Am J Respir Crit Care Med 2002; 165:277-304.

13. Schlesinger C, Koss MN. The organizing pneumonias: an update and review. Curr Opin Pulm Med 2005; 11:422-430.

14. Schlesinger C, Meyer CA, Veeraraghavan S, Koss MN. Constrictive (obliterative) bronchiolitis: diagnosis, etiology, and a critical review of the literature. Ann Diagn Pathol 1998; 2:321-334.

15. Dikensoy O, Bayram N, Bingol A, Filiz A. Bronchiolitis obliterans in a case of juvenile rheumatoid arthritis presented with pneumomediastinum. Respiration 2002; 69:100-102.

16. Tanvetyanon T, Toor AA, Stiff PJ. Post-transplant air-leak syndrome. Br J Haematol 2004; 126:758. 
17. Kumar S, Tefferi A. Spontaneous pneumomediastinum and subcutaneous emphysema complicating bronchiolitis obliterans after allogeneic bone marrow transplantation—case report and review of literature. Ann Hematol 2001; 80:430-435.

18. Hansell DM, Rubens MB, Padley SP, Wells AU. Obliterative bronchiolitis: individual CT signs of small airways disease and functional correlation. Radiology 1997; 203:721-726.

19. Copley SJ, Wells AU, Muller NL, et al. Thin-section CT in obstructive pulmonary disease: discriminatory value. Radiology 2002; 223:812-819.

20. Yousem SA, Berry GJ, Cagle PT, et al. Revision of the 1990 working formulation for the classification of pulmonary allograft rejection: Lung Rejection Study Group. J Heart Lung Transplant 1996; 15:1-15.

21. Pomerance A, Madden B, Burke MM, Yacoub MH. Transbronchial biopsy in heart and lung transplantation: clinicopathologic correlations. J Heart Lung Transplant 1995; 14:761-773.

22. Kramer MR, Stoehr C, Whang JL, et al. The diagnosis of obliterative bronchiolitis after heart-lung and lung transplantation: low yield of transbronchial lung biopsy. J Heart Lung Transplant 1993; 12:675-681.

23. Trulock EP. Management of lung transplant rejection. Chest 1993; 103:1566-1576.

24. Yousem SA, Paradis IL, Dauber JH, Griffith BP. Efficacy of transbronchial lung biopsy in the diagnosis of bronchiolitis obliterans in heart-lung transplant recipients. Transplantation 1989; 47:893-895.

25. Yousem SA, Paradis I, Griffith BP. Can transbronchial biopsy aid in the diagnosis of bronchiolitis obliterans in lung transplant recipients? Transplantation 1994; 57:151-153.

26. Chamberlain D, Maurer J, Chaparro C, Idolor L. Evaluation of transbronchial lung biopsy specimens in the diagnosis of bronchiolitis obliterans after lung transplantation. J Heart Lung Transplant 1994; 13:963-971.

27. Halvorsen RA, Jr., DuCret RP, Kuni CC, Olivari MT, Tylen U, Hertz MI. Obliterative bronchiolitis following lung transplantation. Diagnostic utility of aerosol ventilation lung scanning and high resolution CT. Clin Nucl Med 1991; 16:256-258.

28. Cook RC, Fradet G, Muller NL, Worsely DF, Ostrow D, Levy RD. Noninvasive investigations for the early detection of chronic airways dysfunction following lung transplantation. Can Respir J 2003; 10:76-83.

29. Muller NL. Advances in imaging. Eur Respir J 2001; 18:867-871.

30. de Lange EE, Mugler JP, 3rd, Brookeman JR, et al. Lung air spaces: MR imaging evaluation with hyperpolarized $3 \mathrm{He}$ gas. Radiology 1999; 210:851-857.

31. McAdams HP, Palmer SM, Donnelly LF, Charles HC, Tapson VF, MacFall JR. Hyperpolarized 3He-enhanced MR imaging of lung transplant recipients: preliminary results. AJR Am J Roentgenol 1999; 173:955-959.

32. Lynch DA. Imaging of small airways disease. Clin Chest Med 1993; 14:623-634.

33. Garg K, A. LD, Newell JD, King TE. Proliferative and constrictive bronchiolitis: classification and radiologic features. AJR Am J Roentgenol 1994; 162:803-808.

34. McLoud TC, Epler GR, Colby TV, Gaensler EA, Carrington CB. Bronchiolitis obliterans. Radiology 1986; 159:1-8.

35. Breatnach E, Kerr I. The radiology of cryptogenic obliterative bronchiolitis. Clin Radiol 1982; 33:657-661.

36. Morrish WF, Herman SJ, Weisbrod GL, Chamberlain DW. Bronchiolitis obliterans after lung transplantation: findings at chest radiography and high-resolution CT. Radiology 1991; 179:487-490.

37. Dawson KP, Long A, Kennedy J, Mogridge N. The chest radiograph in acute bronchiolitis. J Paediatr Child Health 1990; 26:209-211.

38. Davies HD, Wang EE, Manson D, Babyn P, Shuckett B. Reliability of the chest radiograph in the diagnosis of lower respiratory infections in young children. Pediatr Infect Dis J 1996; 15:600-604.

39. Hansell DM. Small airways diseases: detection and insights with computed tomography. Eur Respir J 2001; 17: 1294-1313.

40. Kim CK, Kim SW, Kim JS, et al. Bronchiolitis obliterans in the 1990s in Korea and the United States. Chest 2001; 120:1101-1106.

41. Sweatman MC, Millar AB, Strickland B, Turner-Warwick M. Computed tomography in adult obliterative bronchiolitis. Clin Radiol 1990; 41:116-119.

42. Eber CD, Stark P, Bertozzi P. Bronchiolitis obliterans on high-resolution CT: a pattern of mosaic oligemia. J Comput Assist Tomogr 1993; 17:853-856.

43. Lau DM, Siegel MJ, Hildebolt CF, Cohen AH. Bronchiolitis obliterans syndrome: thin-section CT diagnosis of obstructive changes in infants and young children after lung transplantation. Radiology 1998; 208:783-788.

44. Lynch DA, Brasch RC, Hardy KA, Webb WR. Pediatric pulmonary disease: assessment with high-resolution ultrafast CT. Radiology 1990; 176:243-248.

45. Worthy SA, Müller NL, Hartman TE, Swensen SJ, Padley SP, Hansell DM. Mosaic attenuation pattern on thin-section CT scans of the lung: differentiation among infiltrative lung, airway, and vascular diseases as a cause. Radiology 1997; 205:465-470.

46. Worthy SA, Park CS, Kim JS, Müller NL. Bronchiolitis obliterans after lung transplantation: high resolution CT findings in 15 patients. AJR Am J Roentgenol 1997; 169:673-677.

47. Jensen SP, Lynch DA, Brown KK, Wenzel SE, Newell JD. High-resolution CT features of severe asthma and bronchiolitis obliterans. Clin Radiol 2002; 57:1078-1085. 
48. Webb WR, Stern EJ, Kanth N, Gamsu G. Dynamic pulmonary CT: findings in normal adult men. Radiology 1993; 186:117-124.

49. Stern EJ, Webb WR. Dynamic imaging of lung morphology with ultrafast high-resolution computed tomography. $J$ Thorac Imag 1993; 8:273-282.

50. Stern EJ, Frank MS. Small-airway diseases of the lungs: findings at expiratory CT. AJR Am J Roentgenol 1994; $163: 37-41$.

51. Sweatman MC, Millar AB, Strickland B, Turner-Warwick M. Computed tomography in adult obliterative bronchiolitis. Clin Radiol 1990; 41:116-119.

52. Arakawa H, Webb WR, McCowin M, Katsou G, Lee KN, Seitz RF. Inhomogeneous lung attenuation at thin-section CT: diagnostic value of expiratory scans. Radiology 1998; 206:89-94.

53. Stern EJ, Webb WR, Gamsu G. Dynamic quantitative computed tomography: a predictor of pulmonary function in obstructive lung diseases. Invest Radiol 1994; 29:564-569.

54. Gotway MB, Lee ES, Reddy GP, Golden JA, Webb WR. Low-dose, dynamic, expiratory thin-section CT of the lungs using a spiral CT scanner. J Thorac Imaging 2000; 15:168-172.

55. Lucidarme O, Grenier PA, Cadi M, Mourey-Gerosa I, Benali K, Cluzel P. Evaluation of air trapping at CT: comparison of continuous-versus suspended-expiration CT techniques. Radiology 2000; 216:768-772.

56. Remy-Jardin M, Remy J, Gosselin B, Copin MC, Wurtz A, Duhamel A. Sliding thin slab, minimum intensity projection technique in the diagnosis of emphysema: histopathologic-CT correlation. Radiology 1996; 200:665-671.

57. Bhalla M, Naidich DP, McGuinness G, Gruden JF, Leitman BS, McCauley DI. Diffuse lung disease: assessment with helical CT-preliminary observations of the role of maximum and minimum intensity projection images [see comments]. Radiology 1996; 200:341-347.

58. Yang GZ, Hansell DM. CT image enhancement with wavelet analysis for the detection of small airways disease. IEEE Trans Med Imaging 1997; 16:953-961.

59. Fotheringham T, Chabat F, Hansell DM, et al. A comparison of methods for enhancing the detection of areas of decreased attenuation on CT caused by airways disease. J Comput Assist Tomogr 1999; 23:385-389.

60. Wittram C, Batt J, Rappaport DC, Hutcheon MA. Inspiratory and expiratory helical CT of normal adults: comparison of thin section scans and minimum intensity projection images. J Thorac Imaging 2002; 17:47-52.

61. Wittram C, Rappaport DC. Bronchiolitis obliterans after lung transplantation: appearance on expiratory minimum intensity projection images. Can Assoc Radiol J 2000; 51:103-106.

62. Lentz D, Bergin CJ, Berry GJ, Stoehr C, Theodore J. Diagnosis of bronchiolitis obliterans in heart-lung transplantation patients: importance of bronchial dilatation on CT. AJR Am J Roentgenol 1992; 159:463-467.

63. Lynch DA, Newell JD, Tschomper BA, Cink TM, Newman LS, Bethel R. Uncomplicated asthma in adults: comparison of CT appearance of the lungs in asthmatic and healthy subjects. Radiology 1993; 188:829-833.

64. Hansell DM, Wells AU, Padley SP, Müller NL. Hypersensitivity pneumonitis: correlation of individual CT patterns with functional abnormalities. Radiology 1996; 199:123-128.

65. Remy-Jardin M, Remy J, Wallaert B, Müller NL. Subacute and chronic bird breeder hypersensitivity pneumonitis: sequential evaluation with CT and correlation with lung function tests and bronchoalveolar lavage. Radiology 1993; 198:111-118.

66. Small JH, Flower CD, Traill ZC, Gleeson FV. Air-trapping in extrinsic allergic alveolitis on computed tomography. Clin Radiol 1996; 51:684-688.

67. Remy-Jardin M, Remy J, Louvegny S, Artaud D, Deschildre F, Duhamel A. Airway changes in chronic pulmonary embolism: CT findings in 33 patients. Radiology 1997; 203:355-360.

68. Arakawa H, Kurihara Y, Sasaka K, Nakajima Y, Webb WR. Air trapping on CT of patients with pulmonary embolism. AJR Am J Roentgenol 2002; 178:1201-1207.

69. Park CS, Müller NL, Worthy SA, Kim JS, Awadh N, Fitzgerald M. Airway obstruction in asthmatic and healthy individuals: inspiratory and expiratory thin-section CT findings. Radiology 1997; 203:361-367.

70. Lee KW, Chung SY, Yang I, Lee Y, Ko EY, Park MJ. Correlation of aging and smoking with air trapping at thin-section CT of the lung in asymptomatic subjects. Radiology 2000; 214:831-836.

71. Tanaka N, Matsumoto T, Miura G, et al. Air trapping at CT: high prevalence in asymptomatic subjects with normal pulmonary function. Radiology 2003; 227:776-785.

72. Lucidarme O, Coche E, Cluzel P, Mourey-Gerosa I, Howarth N, Grenier P. Expiratory CT scans for chronic airway disease: correlation with pulmonary function test results. AJR Am J Roentgenol 1998; 170:301-307.

73. Mastora I, Remy-Jardin M, Sobaszek A, Boulenguez C, Remy J, Edme JL. Thin-section CT finding in 250 volunteers: assessment of the relationship of CT findings with smoking history and pulmonary function test results. Radiology 2001; 218:695-702.

74. Verschakelen JA, Scheinbaum K, Bogaert J, Demedts M, Lacquet LL, Baert AL. Expiratory CT in cigarette smokers: correlation between areas of decreased lung attenuation, pulmonary function tests and smoking history. Eur Radiol 1998; 8:1391-1399. 
75. Davies CW, Tasker AD, Padley SP, Davies RJ, Gleeson FV. Air trapping in sarcoidosis on computed tomography: correlation with lung function. Clin Radiol 2000; 55:217-221.

76. Terasaki H, Fujimoto K, Muller NL, et al. Pulmonary sarcoidosis: comparison of findings of inspiratory and expiratory high-resolution CT and pulmonary function tests between smokers and nonsmokers. AJR Am J Roentgenol 2005; 185:333-338.

77. Magkanas E, Voloudaki A, Bouros D, et al. Pulmonary sarcoidosis. Correlation of expiratory high-resolution CT findings with inspiratory patterns and pulmonary function tests. Acta Radiol 2001; 42:494-501.

78. Chang AB, Masel JP, Masters B. Post-infectious bronchiolitis obliterans: clinical, radiological and pulmonary function sequelae. Pediatr Radiol 1998; 28:23-29.

79. Hertz MI, Taylor DO, Trulock EP, et al. The registry of the international society for heart and lung transplantation: nineteenth official report-2002. J Heart Lung Transplant 2002; 21:950-970.

80. Keller CA, Cagle PT, Brown RW, Noon G, Frost AE. Bronchiolitis obliterans in recipients of single, double, and heart-lung transplantation. Chest 1995; 107:973-980.

81. Afessa B, Litzow MR, Tefferi A. Bronchiolitis obliterans and other late onset non-infectious pulmonary complications in hematopoietic stem cell transplantation. Bone Marrow Transplant 2001; 28:425-434.

82. Chien JW, Martin PJ, Gooley TA, et al. Airflow obstruction after myeloablative allogeneic hematopoietic stem cell transplantation. Am J Respir Crit Care Med 2003; 168:208-214.

83. King TE, Jr. Miscellaneous causes of bronchiolitis: inhalational, infectious, drug-induced, and idiopathic. Semin Respir Crit Care Med 2003; 24:567-576.

84. Wells AU, duBois RM. Bronchiolitis in association with connective tissue diseases. Clin Chest Med 1993; 14:655-666.

85. Geddes DM, Corrin B, Brewerton DA, Davies RJ, Turner-Warwick M. Progressive airway obliteration in adults and its association with rheumatoid disease. Q J Med 1977; 46:427-444.

86. Remy-Jardin M, Remy J, Cortet B, Mauri F, Delcambre B. Lung changes in rheumatoid arthritis: CT findings. Radiology 1994; 193:375-382.

87. White ES, Tazelaar HD, Lynch JP, 3rd. Bronchiolar complications of connective tissue diseases. Semin Respir Crit Care Med 2003; 24:543-566.

88. Hakala M, Paakko P, Sutinen S, Huhti E, Koivisto O, Tarkka M. Association of bronchiolitis with connective tissue disorders. Ann Rheum Dis 1986; 45:656-662.

89. Boehler A, Vogt P, Speich R, Weder W, Russi EW. Bronchiolitis obliterans in a patient with localized scleroderma treated with D-penicillamine. Eur Respir J 1996; 9:1317-1319.

90. Yousem SA. The pulmonary pathologic manifestations of the CREST syndrome. Hum Pathol 1990; 21:467-474.

91. Turner-Warwick M. Adverse reactions affecting the lung: possible association with D-penicillamine. J Rheumatol Suppl 1981; 7:166-168.

92. Chang H, Wang JS, Tseng HH, Lai RS, Su JM. Histopathological study of Sauropus androgynus-associated constrictive bronchiolitis obliterans: a new cause of constrictive bronchiolitis obliterans [see comments]. Am J Surg Pathol 1997; 21:35-42.

93. Ger LP, Chiang AA, Lai RS, Chen SM, Tseng CJ. Association of Sauropus androgynus and bronchiolitis obliterans syndrome: a hospital-based case-control study. Am J Epidemiol 1997; 145:842-849.

94. Lai RS, Chiang AA, Wu MT, et al. Outbreak of bronchiolitis obliterans associated with consumption of Sauropus androgynus in Taiwan. Lancet 1996; 348:83-85.

95. Aguayo SM, Miller YE, Waldron JA, Jr., et al. Brief report: idiopathic diffuse hyperplasia of pulmonary neuroendocrine cells and airways disease. N Engl J Med 1992; 327:1285-1288.

96. Lee JS, Brown KK, Cool C, Lynch DA. Diffuse pulmonary neuroendocrine cell hyperplasia: radiologic and clinical features. J Comput Assist Tomogr 2002; 26:180-184.

97. Brown MJ, English J, Müller NL. Bronchiolitis obliterans due to neuroendocrine hyperplasia: high-resolution CT and pathologic correlation. AJR Am J Roentgenol 1997; 168:1561-1562.

98. Wilcox P, Miller R, Miller G, et al. Airway involvement in ulcerative colitis. Chest 1987; 92:18-22.

99. Mahadeva R, Walsh G, Flower CD, Shneerson JM. Clinical and radiological characteristics of lung disease in inflammatory bowel disease. Eur Respir J 2000; 15:41-48.

100. Tsunoda N, Iwanaga T, Saito T, Kitamura S, Saito K. Rapidly progressive bronchiolitis obliterans associated with Stevens-Johnson syndrome. Chest 1990; 98:243-245.

101. Mar WA, Glaesser R, Struble K, Stephens-Groff S, Bangert J, Hansen RC. Paraneoplastic pemphigus with bronchiolitis obliterans in a child. Pediatr Dermatol 2003; 20:238-242.

102. Grenier P, Mourey-Gerosa I, Benali K, et al. Abnormalities of the airways and lung parenchyma in asthmatics: CT observations in 50 patients and inter- and intraobserver variability. Eur Radiol 1996; 6:199-206.

103. Silva CI, Colby TV, Muller NL. Asthma and associated conditions: high-resolution CT and pathologic findings. AJR Am J Roentgenol 2004; 183:817-824.

104. Lynch DA, Newell J, Hale V, et al. Correlation of CT findings with clinical evaluations in 261 patients with symptomatic bronchiectasis. AJR Am J Roentgenol 1999; 173:53-58. 
105. Helbich TH, Heinz-Peer G, Eichler I, et al. Cystic fibrosis: CT assessment of lung involvement in children and adults. Radiology 1999; 213:537-544.

106. Kraft M, Mortenson RL, Colby TV, Newman L, Waldron JA, Jr., King TE, Jr. Cryptogenic constrictive bronchiolitis. A clinicopathologic study. Am Rev Respir Dis 1993; 148:1093-1101.

107. Marrie TJ, Poulin-Costello M, Beecroft MD, Herman-Gnjidic Z. Etiology of community-acquired pneumonia treated in an ambulatory setting. Respir Med 2005; 99:60-65.

108. Rocholl C, Gerber K, Daly J, Pavia AT, Byington CL. Adenoviral infections in children: the impact of rapid diagnosis. Pediatrics 2004; 113:e51-56.

109. Kim CK, Chung CY, Kim JS, Kim WS, Park Y, Koh YY. Late abnormal findings on high-resolution computed tomography after Mycoplasma pneumonia. Pediatrics 2000; 105:372-378.

110. Milner AD, Murray M. Acute bronchiolitis in infancy: treatment and prognosis. Thorax 1989; 44:1-5.

111. Yalcin E, Dogru D, Haliloglu M, Ozcelik U, Kiper N, Gocmen A. Postinfectious bronchiolitis obliterans in children: clinical and radiological profile and prognostic factors. Respiration 2003; 70:371-375.

112. Zhang L, Irion K, Kozakewich H, et al. Clinical course of postinfectious bronchiolitis obliterans. Pediatr Pulmonol 2000; 29:341-350.

113. Chuang YY, Chiu CH, Wong KS, et al. Severe adenovirus infection in children. J Microbiol Immunol Infect 2003; 36:37-40.

114. Bloch KE, Weder W, Boehler A, Zalunardo MP, Russi EW. Successful lung volume reduction surgery in a child with severe airflow obstruction and hyperinflation due to constrictive bronchiolitis. Chest 2002; 122:747-750.

115. Zhang L, Irion K, da Silva Porto N, Abreu e Silva F. High-resolution computed tomography in pediatric patients with postinfectious bronchiolitis obliterans. J Thorac Imaging 1999; 14:85-89.

116. Marti-Bonmati L, Ruiz PF, Catala F, Mata JM, Calonge E. CT findings in Swyer-James syndrome. Radiology 1989; 172:477-480.

117. Moore ADA, Godwin JD, Dietrich PA, Verschakelen JA, Henderson WR. Swyer-James syndrome: CT findings in eight patients. AJR Am J Roentgenol 1992; 158:1211-1215.

118. Norton KI, Mendelson DS, Hodes D, Kattan M. Computed tomography findings in the Swyer-James syndrome. Clin Imaging 1989; 13:48-50.

119. Stern EJ, Samples TL. Dynamic ultrafast high resolution CT findings in a case of Swyer-James syndrome. Pediatr Radiol 1992; 22:350-352.

120. Sundaresan S, Trulock EP, Mohanakumar T, Cooper JD, Patterson GA. Prevalence and outcome of bronchiolitis obliterans syndrome after lung transplantation. Washington University Lung Transplant Group. Ann Thorac Surg 1995; 60:1341-1346; discussion 1346-1347.

121. Reichenspurner H, Girgis RE, Robbins RC, et al. Stanford experience with obliterative bronchiolitis after lung and heart-lung transplantation. Ann Thorac Surg 1996; 62:1467-1472; discussion 1472-1463.

122. Valentine VG, Robbins RC, Berry GJ, et al. Actuarial survival of heart-lung and bilateral sequential lung transplant recipients with obliterative bronchiolitis. J Heart Lung Transplant 1996; 15:371-383.

123. Reichenspurner H, Girgis RE, Robbins RC, et al. Obliterative bronchiolitis after lung and heart-lung transplantation. Ann Thorac Surg 1995; 60:1845-1853.

124. Dauber JH. Posttransplant bronchiolitis obliterans syndrome. Where have we been and where are we going? [editorial; comment]. Chest 1996; 109:857-859.

125. Worthy SA, Flint JD, Müller NL. Pulmonary complications after bone marrow transplantation: high-resolution CT and pathologic findings. RadioGraphics 1997; 17:1359-1371.

126. Paradis I, Yousem S, Griffith B. Airway obstruction and bronchilitis obliterans after lung transplantation. Clin Chest Med 1993; 14:751-763.

127. Clark JG, Crawford SW, Madtes DK, Sullivan KM. Obstructive lung disease after allogeneic marrow transplantation. Clinical presentation and course. Ann Intern Med 1989; 111:368-376.

128. St John RC, Gadek JE, Tutschka PJ, Kapoor N, Dorinsky PM. Analysis of airflow obstruction by bronchoalveolar lavage following bone marrow transplantation. Implications for pathogenesis and treatment. Chest 1990; 98:600-607.

129. Guilinger RA, Paradis IL, Dauber JH, et al. The importance of bronchoscopy with transbronchial biopsy and bronchoalveolar lavage in the management of lung transplant recipients. Am J Respir Crit Care Med 1995; 152: 2037-2043.

130. Aboyoun CL, Tamm M, Chhajed PN, et al. Diagnostic value of follow-up transbronchial lung biopsy after lung rejection. Am J Respir Crit Care Med 2001; 164:460-463.

131. Cooper JD, Billingham M, Egan T, et al. A working formulation for the standardization of nomenclature and for clinical staging of chronic dysfunction in lung allografts. International Society for Heart and Lung Transplantation. J Heart Lung Transplant 1993; 12:713-716.

132. Estenne M, Maurer JR, Boehler A, et al. Bronchiolitis obliterans syndrome 2001: an update of the diagnostic criteria. $J$ Heart Lung Transplant 2002; 21:297-310. 
133. Nathan SD, Ross DJ, Belman MJ, et al. Bronchiolitis obliterans in single-lung transplant recipients. Chest 1995; 107:967-972.

134. Boehler A, Estenne M. Post-transplant bronchiolitis obliterans. Eur Respir J 2003; 22:1007-1018.

135. Watkins TR, Chien JW, Crawford SW. Graft versus host-associated pulmonary disease and other idiopathic pulmonary complications after hematopoietic stem cell transplant. Semin Respir Crit Care Med 2005; 26:482-489.

136. Paz HL, Crilley P, Patchefsky A, Schiffman RL, Brodsky I. Bronchiolitis obliterans after autologous bone marrow transplantation. Chest 1992; 101:775-778.

137. Dudek AZ, Mahaseth H, DeFor TE, Weisdorf DJ. Bronchiolitis obliterans in chronic graft-versus-host disease: analysis of risk factors and treatment outcomes. Biol Blood Marrow Transplant 2003; 9:657-666.

138. Adjaoud D, Dauger S, Yakouben K, et al. Reversible severe air leak syndrome in a child with bronchiolitis obliterans after allogeneic stem cell transplantation. Eur J Pediatr 2006; 165:579-580.

139. Galanis E, Litzow MR, Tefferi A, Scott JP. Spontaneous pneumomediastinum in a patient with bronchiolitis obliterans after bone marrow transplantation. Bone Marrow Transplant 1997; 20:695-696.

140. Hill G, Helenglass G, Powles R, Perren T, Selby P. Mediastinal emphysema in marrow transplant recipients. Bone Marrow Transplant 1987; 2:315-320.

141. Heng D, Sharples LD, McNeil K, Stewart S, Wreghitt T, Wallwork J. Bronchiolitis obliterans syndrome: incidence, natural history, prognosis, and risk factors. J Heart Lung Transplant 1998; 17:1255-1263.

142. Sharples LD, McNeil K, Stewart S, Wallwork J. Risk factors for bronchiolitis obliterans: a systematic review of recent publications. J Heart Lung Transplant 2002; 21:271-281.

143. Bando K, Paradis IL, Similo S, et al. Obliterative bronchiolitis after lung and heart-lung transplantation. An analysis of risk factors and management. J Thorac Cardiovasc Surg 1995; 110:4-13; discussion 13-14.

144. Kroshus TJ, Kshettry VR, Savik K, John R, Hertz MI, Bolman RM, 3rd. Risk factors for the development of bronchiolitis obliterans syndrome after lung transplantation. J Thorac Cardiovasc Surg 1997; 114:195-202.

145. Benden C, Aurora P, Curry J, Whitmore P, Priestley L, Elliott MJ. High prevalence of gastroesophageal reflux in children after lung transplantation. Pediatr Pulmonol 2005; 40:68-71.

146. Hadjiliadis D, Duane Davis R, Steele MP, et al. Gastroesophageal reflux disease in lung transplant recipients. Clin Transplant 2003; 17:363-368.

147. D'Ovidio F, Singer LG, Hadjiliadis D, et al. Prevalence of gastroesophageal reflux in end-stage lung disease candidates for lung transplant. Ann Thorac Surg 2005; 80:1254-1260.

148. Young LR, Hadjiliadis D, Davis RD, Palmer SM. Lung transplantation exacerbates gastroesophageal reflux disease. Chest 2003; 124:1689-1693.

149. Davis RD, Jr., Lau CL, Eubanks S, et al. Improved lung allograft function after fundoplication in patients with gastroesophageal reflux disease undergoing lung transplantation. J Thorac Cardiovasc Surg 2003; 125:533-542.

150. Santo Tomas LH, Loberiza FR, Jr, Klein JP, et al. Risk factors for bronchiolitis obliterans in allogeneic hematopoietic stem-cell transplantation for leukemia. Chest 2005; 128:153-161.

151. Novick RJ, Schafers HJ, Stitt L, et al. Recurrence of obliterative bronchiolitis and determinants of outcome in 139 pulmonary retransplant recipients. J Thorac Cardiovasc Surg 1995; 110:1402-1413; discussion 1413-1404.

152. Novick RJ, Schafers HJ, Stitt L, et al. Seventy-two pulmonary retransplantations for obliterative bronchiolitis: predictors of survival. Ann Thorac Surg 1995; 60:111-116.

153. Novick RJ, Andreassian B, Schafers HJ, et al. Pulmonary retransplantation for obliterative bronchiolitis. Intermediateterm results of a North American-European series. J Thorac Cardiovasc Surg 1994; 107:755-763.

154. Konen E, Gutierrez C, Chaparro C, et al. Bronchiolitis obliterans syndrome in lung transplant recipients: can thin-section CT findings predict disease before its clinical appearance? Radiology 2004; 231:467-473.

155. Bankier AA, Van Muylem A, Knoop C, Estenne M, Gevenois PA. Bronchiolitis obliterans syndrome in heart-lung transplant recipients: diagnosis with expiratory CT. Radiology 2001; 218:533-539.

156. Lee ES, Gotway MB, Reddy GP, Golden JA, Keith FM, Webb WR. Early bronchiolitis obliterans following lung transplantation: accuracy of expiratory thin-section CT for diagnosis. Radiology 2000; 216:472-477.

157. Siegel MJ, Bhalla S, Gutierrez FR, Hildebolt C, Sweet S. Post-lung transplantation bronchiolitis obliterans syndrome: usefulness of expiratory thin-section CT for diagnosis. Radiology 2001; 220:455-462.

158. Leung AN, Fisher K, Valentine V, et al. Bronchiolitis obliterans after lung transplantation: detection using expiratory HRCT. Chest 1998; 113:365-370.

159. Berstad AE, Aalokken TM, Kolbenstvedt A, Bjortuft O. Performance of long-term CT monitoring in diagnosing bronchiolitis obliterans after lung transplantation. Eur J Radiol 2006; 58:124-131.

160. Arakawa H, Webb WR. Air trapping on expiratory high-resolution CT scans in the absence of inspiratory scan abnormalities: correlation with pulmonary function tests and differential diagnosis. AJR Am J Roentgenol 1998; 170:1349-1353.

161. de Jong PA, Dodd JD, Coxson HO, et al. Bronchiolitis obliterans following lung transplantation: early detection using computed tomographic scanning. Thorax 2006; 61:799-804.

162. Zaporozhan J, Ley S, Gast KK, et al. Functional analysis in single-lung transplant recipients: a comparative study of high-resolution CT, 3He-MRI, and pulmonary function tests. Chest 2004; 125:173-181. 
163. Akpinar-Elci M, Travis WD, Lynch DA, Kreiss K. Bronchiolitis obliterans syndrome in popcorn production plant workers. Eur Respir J 2004; 24:298-302.

164. Kreiss K, Gomaa A, Kullman G, Fedan K, Simoes EJ, Enright PL. Clinical bronchiolitis obliterans in workers at a microwave-popcorn plant. N Engl J Med 2002; 347:330-338.

165. Perez T, Remy-Jardin M, Cortet B. Airways involvement in rheumatoid arthritis: clinical, functional, and HRCT findings. Am J Respir Crit Care Med 1998; 157:1658-1665.

166. Herzog CA, Miller RR, Hoidal JR. Bronchiolitis and rheumatoid arthritis. Am Rev Respir Dis 1979; 119:555-560.

167. Schwarz MI, Lynch DA, Tuder R. Bronchiolitis obliterans: the lone manifestation of rheumatoid arthritis? Eur Respir J 1994; 7:817-820.

168. Epler GR, Snider GL, Gaensler EA, Cathcart ES, Fitzgerald MK, Carrington CB. Bronchiolitis and bronchitis in connective tissue disease. JAMA 1979; 242:528-532.

169. Zitnik RJ, Cooper JA, Jr. Pulmonary disease due to antirheumatic agents. Clin Chest Med 1990; 11:139-150.

170. Fujii M, Adachi S, Shimizu T, Hirota S, Sako M, Kono M. Interstitial lung disease in rheumatoid arthritis: assessment with high-resolution computed tomography. J Thorac Imag 1993; 8:54-62.

171. Akira M, Sakatani M, Hara H. Thin-section CT findings in rheumatoid arthritis-associated lung disease: CT patterns and their courses. J Comput Assist Tomogr 1999; 23:941-948.

172. Papiris SA, Maniati M, Constantopoulos SH, Roussos C, Moutsopoulos HM, Skopouli FN. Lung involvement in primary Sjogren's syndrome is mainly related to the small airway disease. Ann Rheum Dis 1999; 58:61-64.

173. Weber F, Prior C, Kowald E, Schmuth M, Sepp N. Cyclophosphamide therapy is effective for bronchiolitis obliterans occurring as a late manifestation of lupus erythematosus. Br J Dermatol 2000; 143:453-455.

174. Yang CF, Wu MT, Chiang AA, et al. Correlation of high-resolution CT and pulmonary function in bronchiolitis obliterans: a study based on 24 patients associated with consumption of Sauropus androgynus. AJR Am J Roentgenol 1997; 168:1045-1050.

175. Oonakahara K, Matsuyama W, Higashimoto I, et al. Living-donor lobar lung transplantation in Sauropus androgynusassociated bronchiolitis obliterans in Japan. Intern Med 2005; 44:1103-1104.

176. Luh SP, Lee YC, Chang YL, Wu HD, Kuo SH, Chu SH. Lung transplantation for patients with end-stage Sauropus androgynus-induced bronchiolitis obliterans (SABO) syndrome. Clin Transplant 1999; 13:496-503.

177. Kerr KM. Pulmonary preinvasive neoplasia. J Clin Pathol 2001; 54:257-271.

178. Miller RR, Muller NL. Neuroendocrine cell hyperplasia and obliterative bronchiolitis in patients with peripheral carcinoid tumors. Am J Surg Pathol 1995; 19:653-658.

179. Travis WD. Pathology of lung cancer. Clin Chest Med 2002; 23:65-81, viii.

180. Cohen AJ, King TE, Jr, Gilman LB, Magill-Solc C, Miller YE. High expression of neutral endopeptidase in idiopathic diffuse hyperplasia of pulmonary neuroendocrine cells. Am J Respir Crit Care Med 1998; 158:1593-1599.

181. Johney EC, Pfannschmidt J, Rieker RJ, Schnabel PA, Mechtersheimer G, Dienemann H. Diffuse idiopathic pulmonary neuroendocrine cell hyperplasia and a typical carcinoid tumor. J Thorac Cardiovasc Surg 2006; 131:1207-1208.

182. Turton CW, Williams G, Green M. Crytogenic obliterative bronchiolitis in adults. Thorax 1981; 36:805-810.

183. Camus P, Colby TV. The lung in inflammatory bowel disease. Eur Respir J 2000; 15:5-10.

184. Camus P, Piard F, Ashcroft T, Gal AA, Colby TV. The lung in inflammatory bowel disease. Medicine (Baltimore) 1993; 72:151-183.

185. Casey MB, Tazelaar HD, Myers JL, et al. Noninfectious lung pathology in patients with Crohn's disease. Am J Surg Pathol 2003; 27:213-219.

186. Spira A, Grossman R, Balter M. Large airway disease associated with inflammatory bowel disease. Chest 1998; 113:1723-1726.

187. Ward H, Fisher KL, Waghray R, Wright JL, Card SE, Cockcroft DW. Constrictive bronchiolitis and ulcerative colitis. Can Respir J 1999; 6:197-200. 